\title{
Summer Indoor Heat Pump Water Heater Evaluation in a Hot-Dry Climate
}

Marc Hoeschele and Matthew Seitzler Alliance for Residential Building Innovation 


\section{NOTICE}

This report was prepared as an account of work sponsored by an agency of the United States government. Neither the United States government nor any agency thereof, nor any of their employees, subcontractors, or affiliated partners makes any warranty, express or implied, or assumes any legal liability or responsibility for the accuracy, completeness, or usefulness of any information, apparatus, product, or process disclosed, or represents that its use would not infringe privately owned rights. Reference herein to any specific commercial product, process, or service by trade name, trademark, manufacturer, or otherwise does not necessarily constitute or imply its endorsement, recommendation, or favoring by the United States government or any agency thereof. The views and opinions of authors expressed herein do not necessarily state or reflect those of the United States government or any agency thereof.

This report is available at no cost from the National Renewable Energy Laboratory (NREL) at www.nrel.gov/publications.

Available electronically at SciTech Connect http:/www.osti.gov/scitech

Available for a processing fee to U.S. Department of Energy and its contractors, in paper, from:

U.S. Department of Energy

Office of Scientific and Technical Information

P.O. Box 62

Oak Ridge, TN 37831-0062

OSTI http://www.osti.gov

Phone: 865.576.8401

Fax: 865.576.5728

Email: reports@osti.gov

Available for sale to the public, in paper, from:

U.S. Department of Commerce

National Technical Information Service

5301 Shawnee Road

Alexandria, VA 22312

NTIS http://www.ntis.gov

Phone: 800.553 .6847 or 703.605 .6000

Fax: 703.605.6900

Email: orders@ntis.gov 


\title{
Summer Indoor Heat Pump Water Heater Evaluation in a Hot-Dry Climate
}

\author{
Prepared for: \\ The National Renewable Energy Laboratory \\ On behalf of the U.S. Department of Energy's Building America Program \\ Office of Energy Efficiency and Renewable Energy \\ 15013 Denver West Parkway \\ Golden, CO 80401 \\ NREL Contract No. DE-AC36-08GO28308 \\ Prepared by: \\ Marc Hoeschele and Matthew Seitzler \\ Alliance for Residential Building Innovation (ARBI) \\ Davis Energy Group, Team Lead \\ 123 C Street \\ Davis, California 95616 \\ NREL Technical Monitor: Stacey Rothgeb \\ Prepared under Subcontract No. KNDJ-0-40340-00
}

May 2017 
The work presented in this report does not represent performance of any product relative to regulated minimum efficiency requirements.

The laboratory and/or field sites used for this work are not certified rating test facilities. The conditions and methods under which products were characterized for this work differ from standard rating conditions, as described.

Because the methods and conditions differ, the reported results are not comparable to rated product performance and should only be used to estimate performance under the measured conditions. 


\section{List of Acronyms}

$\begin{array}{ll}\text { ARBI } & \text { Alliance for Residential Building Innovation } \\ \text { CARB } & \text { Consortium for Advanced Residential Buildings } \\ \text { COP } & \text { coefficient of performance } \\ \text { DHW } & \text { domestic hot water } \\ \text { DOE } & \text { U.S. Department of Energy } \\ \text { EES } & \text { Engineering Equation Solver } \\ \text { EF } & \text { energy factor } \\ \text { gpd } & \text { gallons per day } \\ \text { HPWH } & \text { heat pump water heaters } \\ \text { HVAC } & \text { heating, ventilating, and air conditioning } \\ \text { kBtu } & \text { Thousand British Thermal Units } \\ \text { kW } & \text { kilowatt } \\ \text { kWh } & \text { kilowatt-hour } \\ \text { NEEA } & \text { Northwest Energy Efficiency Alliance } \\ \text { PNNL } & \text { Pacific Northwest National Laboratory } \\ \text { REU } & \text { Redding Electric Utility } \\ \text { RH } & \text { resistance heat } \\ \text { DH } & \end{array}$




\section{Executive Summary}

More than $40 \%$ of U.S. households heat domestic hot water (DHW) using electric-resistance storage water heaters (DOE 2010). For this group, heat pump water heaters (HPWHs) offer a significant opportunity to improve water heating performance. The HPWH technology is making inroads in some U.S. markets due to aggressive marketing and local utility incentives that often contribute to very favorable economics relative to electric-resistance storage water heating.

As an HPWH operates, it results in air being cooled by the evaporator. This cooled air is either directly exhausted to the surrounding space or, with the advent of ducting kits, delivered to a nearby location in or outside conditioned space. The resulting impact on heating and cooling loads varies considerably based on climate, hot water loads, thermostat setpoints, and the thermal characteristics of the building envelope.

Numerous field studies document performance in a variety of climates and applications. More recent evaluation efforts focus on the performance of units located indoors, as many existing electric water heaters are located in conditioned space. Much of the prior work on ducted HPWHs focuses on cold climates or hot-humid areas. To meet the end-of-year project completion constraints, this study evaluated only summer performance of indoor HPWHs installed in two existing homes in Redding, California. Redding is located in a hot, dry region of the state with more than 2,000 annual cooling degree days and 2,827 heating degree days. The existing electric storage water heaters in the two homes were monitored in detail over a fourweek period, followed by the HPWH retrofit in late May. The monitoring included detailed flow and temperature readings at the water heater (at both the water- and air-sides for the HPWH), indoor and outdoor conditions, and space-cooling energy consumption.

Summer results indicated favorable water heating performance-2.60 to 2.85 average coefficient of performance (COP) - and average monitored space cooling delivery from the HPWH in the range of 12,000 to $17,000 \mathrm{Btu}$ /day per day. A combination of high space cooling energy use at the two sites, along with fairly strong variability in cooling usage, made it challenging to resolve the small HPWH cooling benefit from the monitored cooling system energy use. However, given the observed patterns of cooling operation at the two sites and the measured HPWH delivered cooling, annual space cooling energy savings of 121-135 kilowatt-hours (kWh) per year are projected. These savings increase the annual estimated HPWH energy savings by 5-9\%.

Customer satisfaction with the installed HPWHs was generally high with both households valuing the cooling delivery indoors. In addition, one site (a six-person household) strongly noted improved hot water delivery characteristics relative to their prior electric-storage water heater. Although this study focused solely on summer impacts, supplemental funding from partners Redding Electric Utility and Pacific Gas and Electric extended the monitoring period through May 2015. Collecting a full year of monitoring data is valuable in developing a better understanding of annual performance characteristics and customer satisfaction with winter HPWH operation. 


\section{Table of Contents}

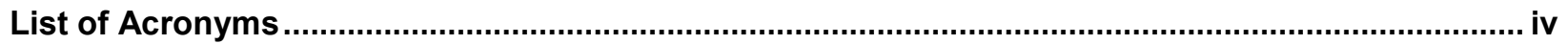

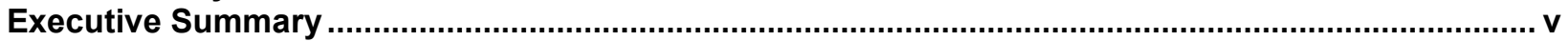

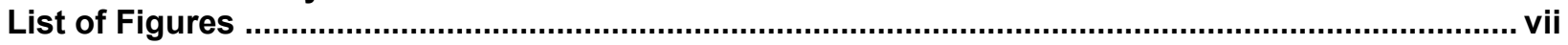

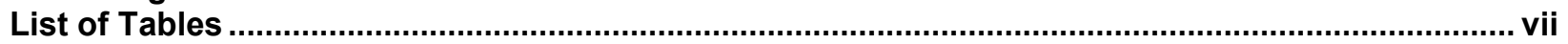

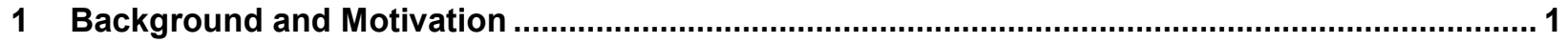

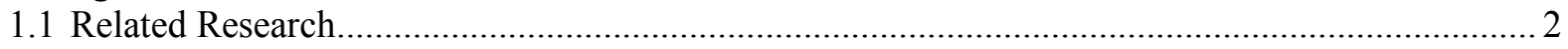

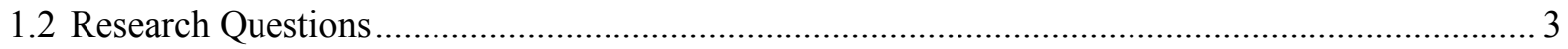

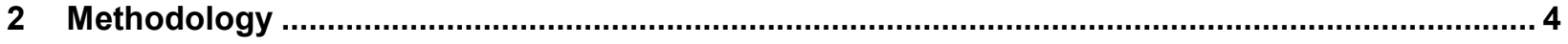

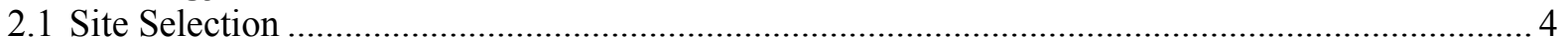

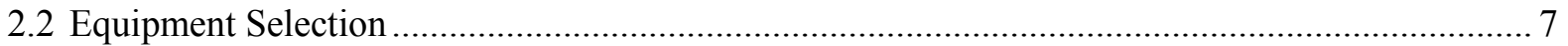

2.3 Heat Pump Water Heater Monitoring Approach .................................................................... 8

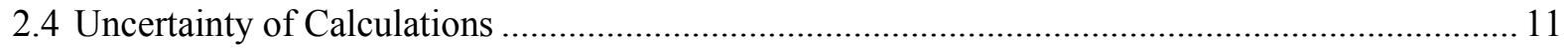

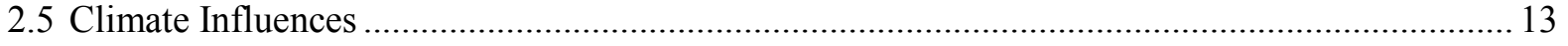

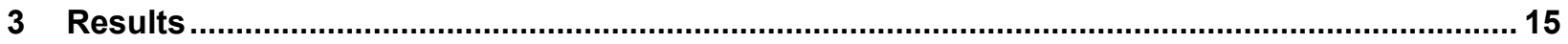

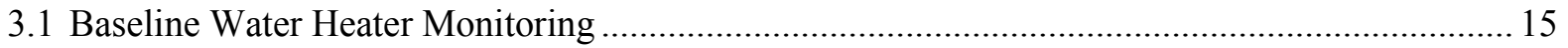

3.2 HPWH System Commissioning and Operational Issues ..................................................... 16

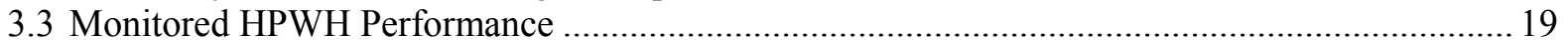

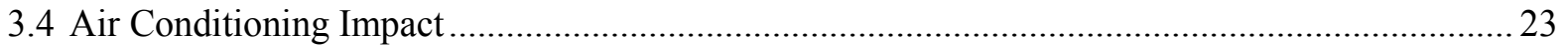

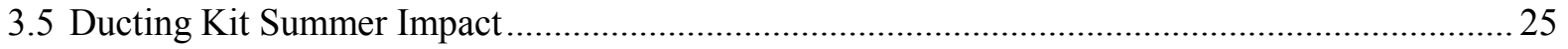

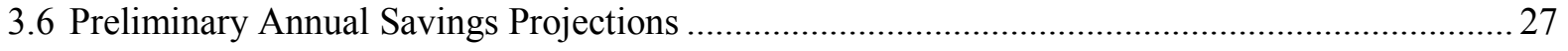

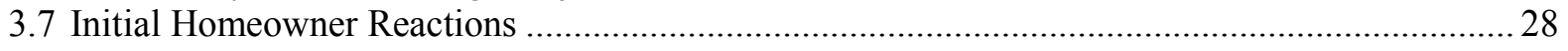

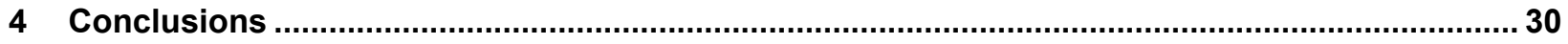

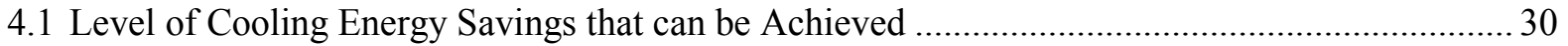

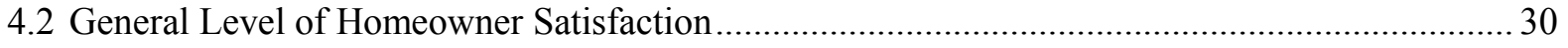

4.3 Recommendations to Improve the Ducted HPWH Installability, Operation, and Performance.... 31

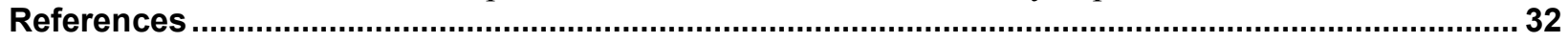

Appendix A: Determination of Preliminary Annual Performance Impacts ....................................... 33 


\section{List of Figures}

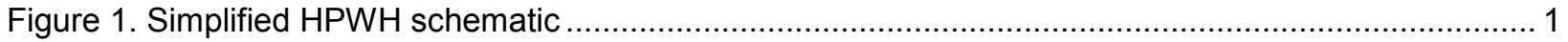

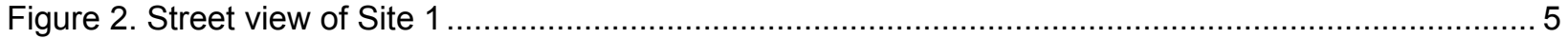

Figure 3. Street view of Site 2

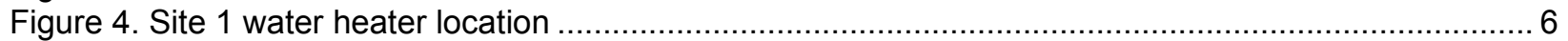

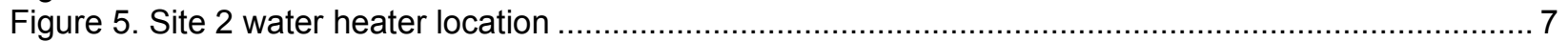

Figure 6. Schematic of ducted HPWH configuration and monitoring points ......................................... 10

Figure 7. Official National Weather Service daily recorded Redding temperatures ............................... 14

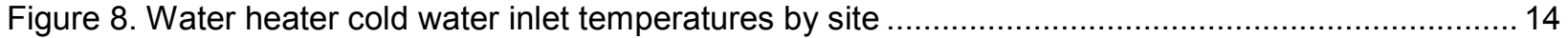

Figure 9. Sample Site 2 electric water heater baseline monitoring .................................................. 15

Figure 10. Baseline electric water heater energy use vs. load ........................................................ 16

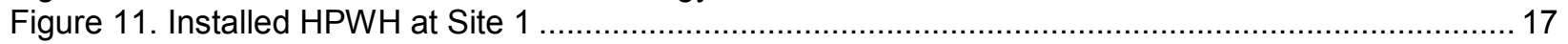

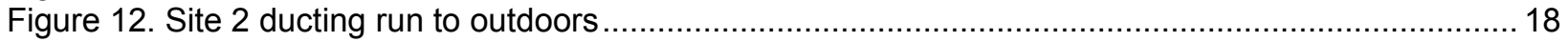

Figure 13. Site 2, HPWH evaporator leaving air discharge to kitchen ................................................ 18

Figure 14. Sample HPWH demand profiles (15 minute interval data) ............................................... 19

Figure 15. Average summer HPWH demand profile (15-minute interval data) ................................... 20

Figure 16. Daily HPWH energy use as a function of hot water use ................................................. 21

Figure 17. Comparison of electric-resistance and HPWH daily energy use ........................................22

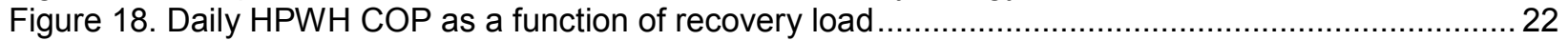

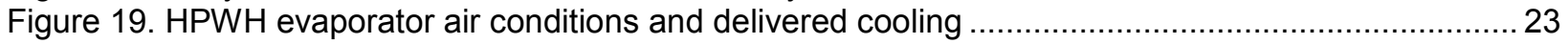

Figure 20. Monitored daily cooling energy use as a function of outdoor maximum temperature ..............24

Figure 21. 15 minute interval indoor temperature data (May 22 - September 14, 2014)....................... 25

Figure 22. Comparison of average HPWH inlet air conditionson entering wet-bulb temperature ..............27

Unless otherwise noted, all figures were created by the ARBI team.

\section{List of Tables}

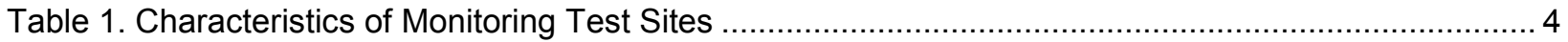

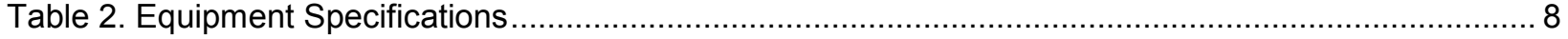

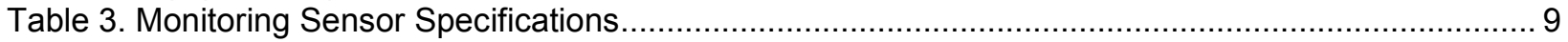

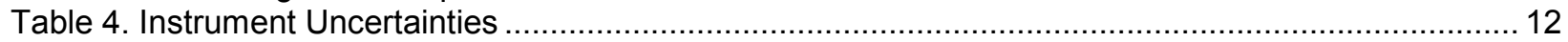

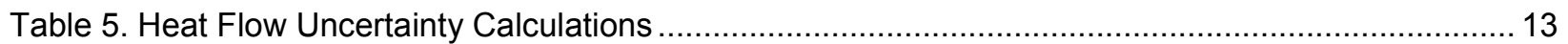

Table 6. Impact of Ducting Kit on Summer HPWH Inlet Conditions ....................................................2 26

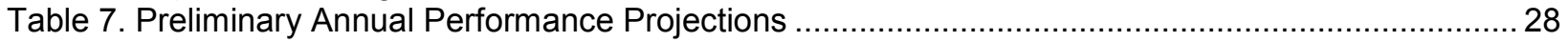

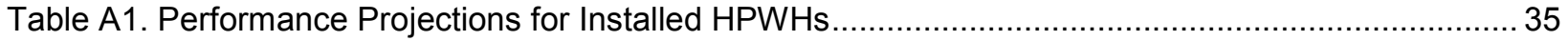




\section{Background and Motivation}

Quantifying the water heating performance and space conditioning impacts of heat pump water heaters (HPWHs) operating within conditioned space is an important Building America research topic as it provides critical data on a broader systems level. This kind of comprehensive field research is needed in a variety of applications and climates to inform not only on the performance and cost-effectiveness implications, but also on issues such as customer satisfaction primarily related to noise. To date, field studies have been undertaken in many parts of the country; however, in terms of indoor HPWH installations, the major research focus has been on assessing performance impacts on space-heating loads. This study expands the understanding of indoor HPWH performance by focusing hot-dry climate applications where cooling load interactions are the primary concern. Monitoring the space-cooling benefits advances Building America research efforts by quantifying performance impacts in a hot-dry climate. With favorable results, this approach could be promoted as a preferred strategy for specific regional applications in both new construction and retrofit applications.

Figure 1 shows how HPWHs operate by taking surrounding air, passing it over the evaporator coil, and exhausting cooler air to the surrounding air space, or into a ducting kit for delivery away from the unit. (Since typical HPWH installation criteria suggest a 700-1000 $\mathrm{ft}^{3}$ volume of adequate dilution of evaporator leaving air, the ducting kit serves as an approach to allow installations in more confined spaces.) More heat than is removed from the evaporator is rejected to the storage tank, based on the operating efficiency of the unit.

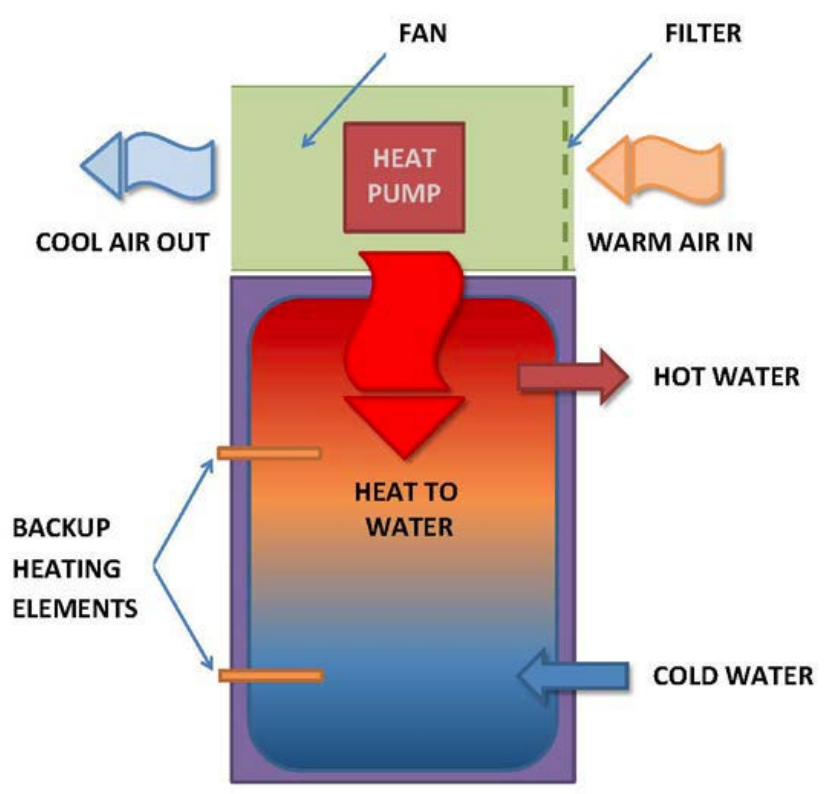

Figure 1. Simplified HPWH schematic

Many HPWHs are installed in unconditioned spaces such as garages and attics, while some are installed in conditioned space such as basements or laundry rooms and interior closets. The units installed in conditioned space impact space conditioning loads to varying extents depending on climate and hot water loads. In heating-dominated climates, the impact is largely negative as additional heat from the space-heating system is needed to offset the evaporator heat removal. In 
mixed climates the impact may be neutral. However, in cooling-dominated climates, an indoor HPWH may be able to generate sufficient cooling season benefits to more than offset any winter heating penalty. It should be noted, however, that the heating season penalty is likely to be greater than the cooling season benefit.

The availability of HPWH ducting kits from several manufacturers allow to seasonally control the airflow paths for air entering and leaving the HPWH. During the summer season, either indoor or outdoor air can enter the HPWH evaporator and cooled air can be delivered indoors. Conversely, in the winter season, the exclusive use of outdoor air and leaving air routed outdoors would eliminate any negative impact on space-heating loads. This improved control allows for optimizing space conditioning impact. Any applications whereby the house can be depressurized with HPWH operation should be carefully evaluated in conjunction with indoor combustion appliances.

\subsection{Related Research}

Prior work in this area includes a monitoring study by NRCan at the twin test houses located in Ottawa, Canada. In this test configuration, the two identical "twins" were calibrated against each other, allowing for equipment changes in one house to be compared to a benchmark system in the second house. Martin Thomas presented results from this study (Heat Pump Water Heaters: Whole House Effects -Heating \& Cooling Seasons) at the 2013 ACEEE Hot Water Forum ${ }^{1}$. In this testing project, one house had an electric storage water heater in the basement and the other had an HPWH. Findings for the Ottawa climate suggest that in the heating season, any HPWH energy savings relative to electric-resistance water heating are essentially offset by space-heating system energy use. In the short Canadian summer season, project findings showed a $20 \%$ reduction in overall house cooling and water heating energy use, amounting to approximately 7 $\mathrm{kWh} /$ day for the "typical" hot water loads used in the study.

The Northwest Energy Efficiency Alliance (NEEA) completed a 30-home field study of HPWHs installed in the Pacific Northwest in late 2013 (Fluid Market Strategies, 2013). Some of the homes included HPWHs with ducting kits, although the focus of that study was on HPWH performance, not on space conditioning impacts. A second ongoing field study of 50 homes is assessing the space conditioning impacts in more detail.

Southface, working under the National Association of Home Builders Research Center IP team, has a project were HPWHs are installed indoors at 15 duplexes in Lafayette, GA. The water heating system is ducted and draws air from, and rejects it to, an encapsulated attic space. Another recent hot/humid project involved the Consortium for Advanced Residential Buildings (CARB) team monitoring a 50-gallon General Electric HPWH installed in the unvented attic of a house in Windmere, FL (Williamson and Puttagunta, 2013). Over a four-month summer period, the unit operated at a COP of 2.2.

NREL completed a detailed Transient System Simulation program modeling study (Maquire et al, 2013) of HPWHs in the seven Building America climate zones to assess both water heating source energy impacts relative to conventional gas and electric storage water heaters, as well as determining both the impact of indoor HPWH operation on space conditioning loads. Detailed

\footnotetext{
${ }^{1}$ http://www.aceee.org/conferences/2013/hwf/program
} 
results are provided in Appendix A. For an indoor 50-gallon HPWH compared to an electric storage water heater in a home conditioned with an air source heat pump, the average annual space cooling source energy benefit was projected to be $41 \%$ of the space-heating penalty. The combined annual space conditioning impact resulted in a $14 \%$ reduction in the water heatingonly savings. In the hot-dry climate, space conditioning is more favorable; however, there is still an overall negative impact on an annual basis (annual space-cooling benefit is $77 \%$ of the annual space-heating penalty).

A recent Pacific Northwest National Laboratory (PNNL) study tested HPWHs in various ducting configurations at two PNNL lab homes that were heavily instrumented (Widder et al, 2014). The study found that in the Richland, WA climate, the penalty of installing a HPWH indoors may not be as large as modeling studies indicate. The report suggests that a fully ducted HPWH decreased heating, ventilating, and air conditioning (HVAC) energy use by $7.8 \% \pm 2.3 \%$ as compared to a case with an unducted HPWH.

\subsection{Research Questions}

The proposed work expands the geographical and climatic documentation of indoor HPWH performance, as well as evaluating the ducting kit impacts. Findings from this and the other projects could be used in refining performance modeling in the Building Energy Optimization model, which currently assumes the HPWH does not interact with indoor thermal systems.

A key focus of this project is to assess indoor HPWH water heating performance and impact on summer space conditioning energy use under various operating modes. As noted previously, the timeline for this research project required completion in 2014, limiting the assessment to summer testing. In addition, the project team is interested in assessing homeowner satisfaction with the HPWH relative to their experiences with their prior electric storage water heater.

Key research questions include the following:

1. What level of cooling energy savings can be achieved by a ducted HPWH in a hot-dry climate with more than 1,900 cooling degree days?

2. What is the general level of homeowner satisfaction with the indoor HPWH in terms of perceived energy savings, hot water delivery characteristics, noise, and thermal comfort impacts?

3. Based on the field testing results, what recommendations can be made to improve the ducted HPWH installability, operation, and performance?

Project partner Redding Electric Utility $(\mathrm{REU})^{2}$, who helped identify sites and supported the installation of the HPWH's for this project, is interested in extending the current Building America-funded effort to continue through the upcoming heating season. Adding the winter performance assessment in a hot-dry climate will help expand the current summer results. Nevertheless, quantifying summer cooling system performance impacts of indoor HPWH's in a hot-dry climate is a critical step in advancing the understanding of HPWH performance in different climates and applications.

\footnotetext{
${ }^{2}$ REU serves 86,000 residential and commercial customers in Northern California.
} 


\section{Methodology}

\subsection{Site Selection}

The Alliance for Residential Building Innovation ARBI team approached REU in the summer of 2013 to assess their interest in participating in a HPWH field monitoring project focused on both water heating performance and impacts on summer cooling load. REU, an all-electric utility located in Northern California, serves approximately 86,000 residential and commercial customers. Although natural gas is available in much of the area, electric storage water heaters are fairly common in their service territory. ARBI, REU, and local high-performance building contractor, The Energy Docs, identified a short list of candidate sites that met the following criteria:

- Existing indoor electric storage water heater

- Interest in participating in the project

- Stable and consistent home occupancy during the 2014 summer.

To encourage participation in the project, REU agreed to cover the cost of installation of the HPWHs for each of the homeowners. The utility is particularly interested in gaining firsthand experience with monitored HPWH locations in their service territory. In addition to understanding summer performance of the HPWHs, they are also interested in funding ongoing monitoring through the winter season.

Two sites were identified that met these criteria. Basic characteristics of the two sites are identified in Table 1.

Table 1. Characteristics of Monitoring Test Sites

\begin{tabular}{|c|c|c|}
\hline Parameter & Site 1 & Site 2 \\
\hline House floor area $\left(\mathrm{ft}^{2}\right)$ & 2,037 (3 story) & 2,740 (2 story) \\
\hline Year constructed & $\sim 1980$ & 1987 \\
\hline Occupants & Two adults & $\begin{array}{c}\text { Six (2 adults, one child }<10, \\
\text { three } 10-20 \text { year olds) }\end{array}$ \\
\hline $\begin{array}{l}\text { Existing electric storage } \\
\text { water heater }\end{array}$ & 50-gallon Bradford, White & 50-gallon Bradford, White \\
\hline $\begin{array}{l}\text { HVAC system } \\
\text { description }\end{array}$ & $\begin{array}{l}\text { Two packaged heat pumps } \\
\text { (age estimated at } 20+\text { years) } \\
\text { 1. BDP 542D032HP } \\
\text { 2. No nameplate on } \\
\text { unit }\end{array}$ & $\begin{array}{l}\text { Two split-system heat pumps } \\
\text { (both original equipment) } \\
\text { 1. Bryant } 663 \text { CJ036 } \\
\text { 2. No nameplate on unit }\end{array}$ \\
\hline
\end{tabular}




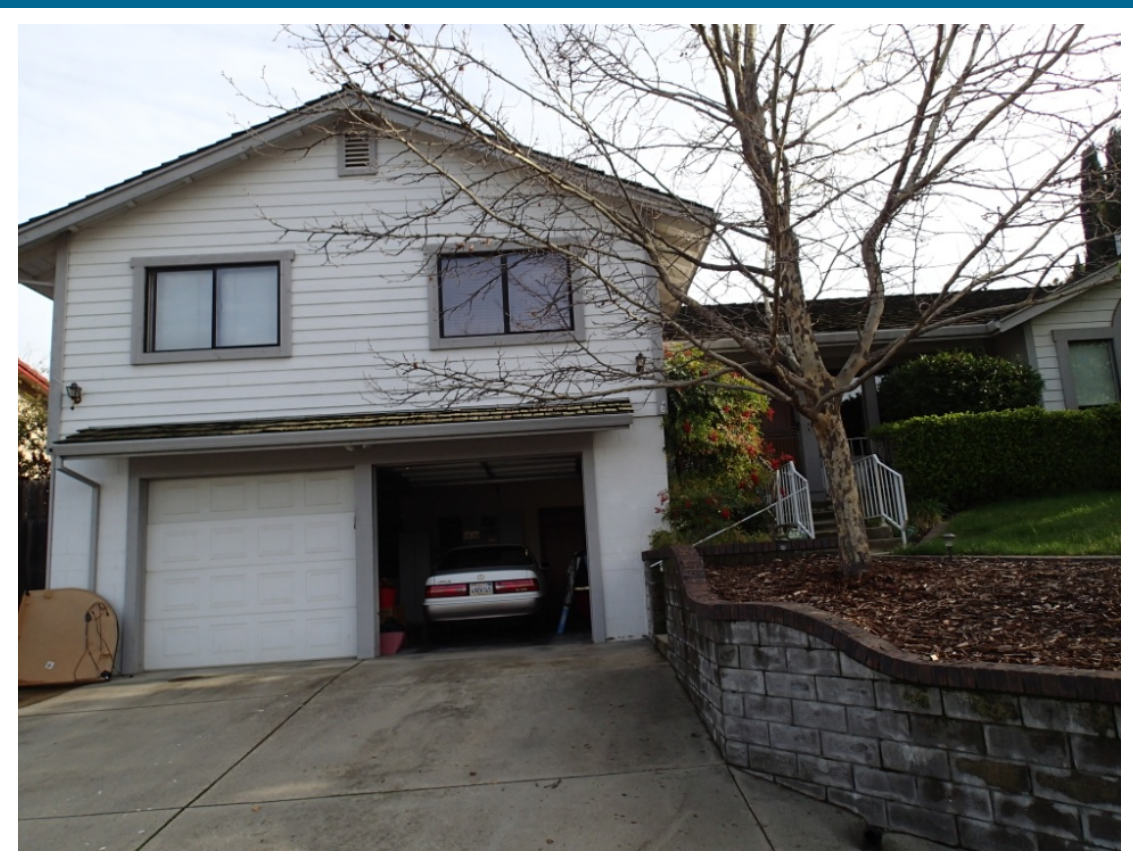

Figure 2. Street view of Site 1

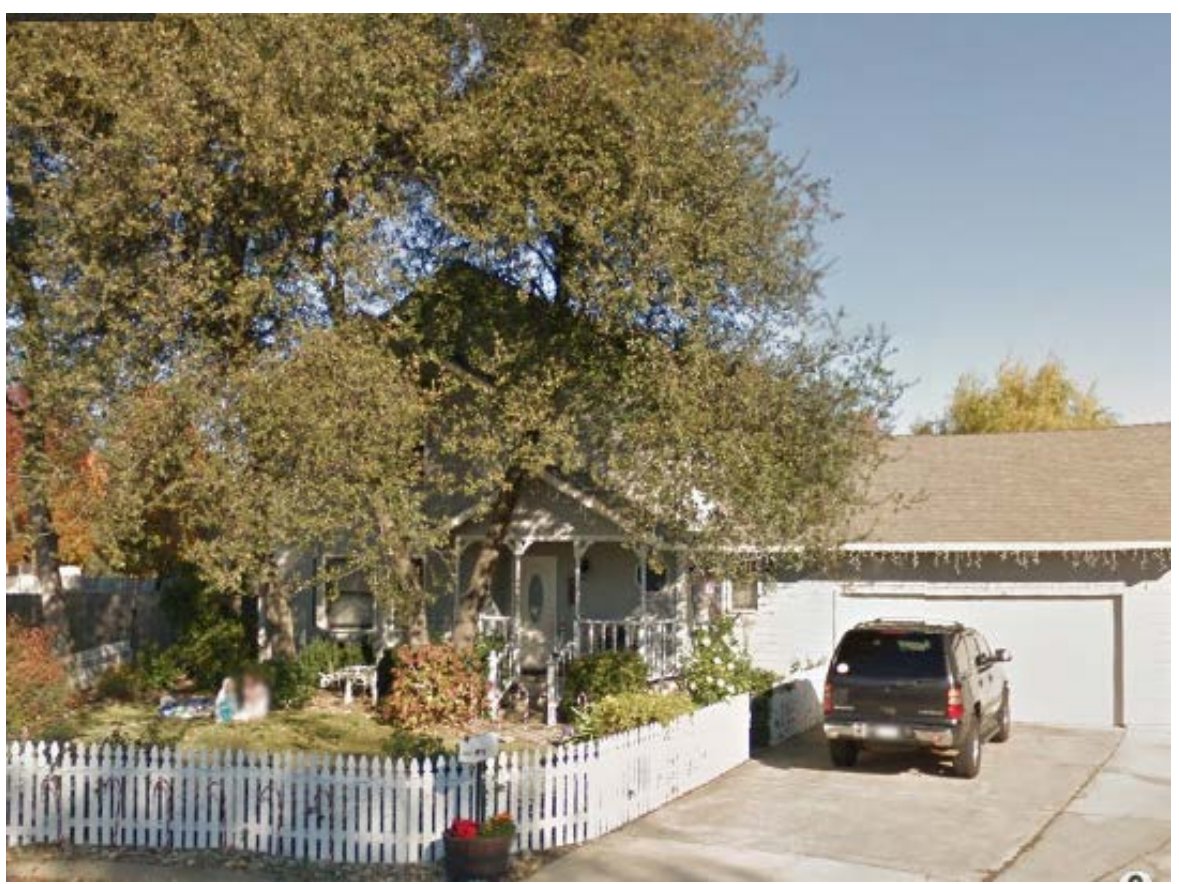

Figure 3. Street view of Site 2

Figure 4 shows the location of the existing electric water heater (within the music studio) at Site 1. The lower floor of the house shown has two floors of living space above. The downstairs is largely built with masonry block wall construction. Although within the thermal envelope, the 
music studio does not have direct space conditioning. At the time of installation, the owners were indirectly cooling the music studio area by opening the door to the wine room. The owners expressed strong interest in adding cooling to the space to supplement the use of fans during hot summer nights. They were also concerned about coring through the block walls to accommodate the ducting as they would likely abandon it at the end of the project. As a result, the HPWH unit was installed in the space without any ducting of air entering or leaving the evaporator. The thermostat controlling the first floor HVAC unit was located on the floor above the water heater location.

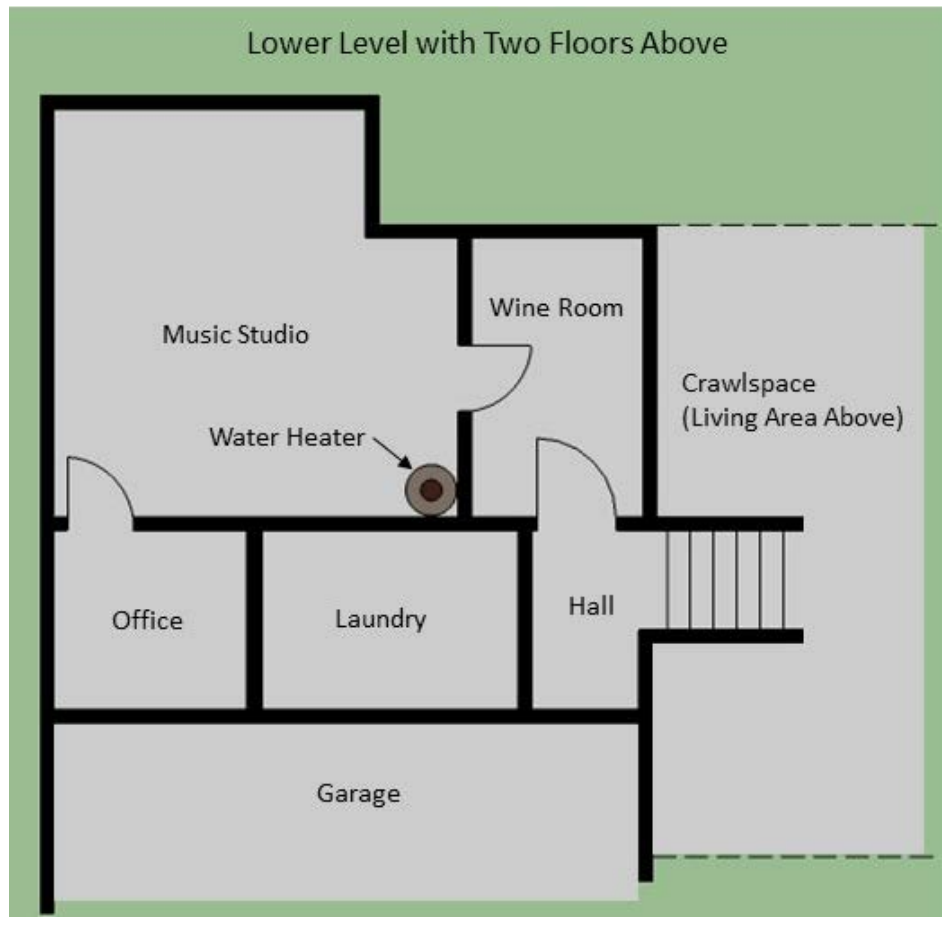

Figure 4. Site 1 water heater location

Figure 5 shows the configuration of the first floor at Site 2. The existing electric water heater is located in the laundry room. This house presented much more flexibility at integrating ducting on the supply and return sides of the HPWH. Approximately 10 feet of six-inch flex duct was added and ducted to the outdoors and to the kitchen register location ${ }^{3}$. As shown in the figure, the concept was to run an inlet duct from outdoors to the unit and a duct leaving the unit to outdoors (via the attic) or to the kitchen area, where additional cooling is often desired in hot climates like Redding. The first floor HVAC unit thermostat is located in the living room area and is far enough removed from the HPWH kitchen supply register as to not be directly impacted by the unit's operation.

\footnotetext{
${ }^{3}$ The manufacturer states that "maximum duct length shall not exceed 25 feet in length and shall not have more than three $90^{\circ}$ elbows"... and for "duct lengths longer than 10 feet, but not exceeding 25 feet, rigid ducting with a smooth inner surface is recommended."
} 


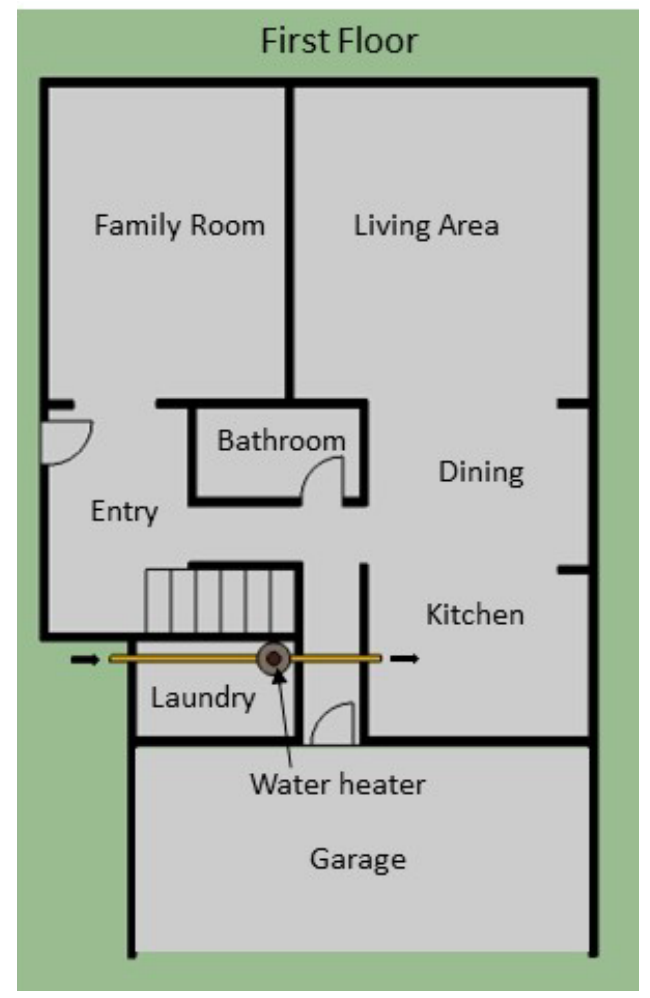

Figure 5. Site 2 water heater location

\subsection{Equipment Selection}

The goal of this project was to install a fully ducted HPWH (both inlet and outlet ducted to conditioned space and outside) in both field sites to be able to test the unit by varying the source of evaporator air and controlling the leaving air delivery to either indoors or outdoors. Several manufacturers provide the capability to fully duct their units including General Electric, A.O. Smith, and Air Generate. In discussions with staff at NEEA, the team selected the Air Generate brand as the preferred choice for this project due primarily to their favorable experiences with the unit in terms of low noise levels ${ }^{4}$. As noted, noise levels are critical to ensuring customer satisfaction.

The ARBI team and The Energy Docs reviewed the household size and demographic information with Air Generate support engineers and determined that appropriate sizing for the two units would be a 66-gallon ATI66 model for Site 1 and an 80-gallon ATI80 for Site 2. Specifications for the two units can be found in Table 2. Typical evaporator airflows are in the range of 250 to $275 \mathrm{cfm}$ unducted, with reduced airflow with the installation of a ducting kit and ductwork.

\footnotetext{
${ }^{4}$ NEEA has had several larger detailed field monitoring studies over the past few years with tens of units being monitored. The observed lower noise levels within this unit were a key factor in selecting this brand versus competing brands.
} 
Table 2. Equipment Specifications

\begin{tabular}{|lcc|}
\hline \multicolumn{1}{|c}{ Parameter } & ATI66 & ATI80 \\
\hline Tank volume & 66 gallons & 80 gallons \\
EF (hybrid mode) & 2.35 & 2.2 \\
First Hour Rating (hybrid mode) & 70 gallons & 80 gallons \\
Heat Pump Btu Rating & $2.5 \mathrm{~kW}$ & $2.5 \mathrm{~kW}$ \\
Backup Electric Element & $4.0 \mathrm{~kW}$ & $4.0 \mathrm{~kW}$ \\
Refrigerant & R410A & R410A \\
Tank Height & $70.5 "$ & $75.5 "$ \\
Weight (dry) & $243 \mathrm{lbs}$ & $254 \mathrm{lbs}$ \\
Duct Kit Connection Diameter & $6 "$ & $6 "$ \\
Decibel Rating & $48 \mathrm{db}$ & $48 \mathrm{db}$ \\
\hline
\end{tabular}

\subsection{Heat Pump Water Heater Monitoring Approach}

The experimental design focused on testing the two installed HPWHs to monitor HPWH performance, as well as to determine resulting summer space cooling energy impacts. The expectation in a hot climate like Redding is that it should be easier to resolve space cooling impacts as the cooling system operates on most of summer days 5 .

The two sites were equipped with Data Electronics DT50 data loggers and modems for collecting, storing, and transferring data on a daily basis to the ARBI host computer at the Davis Energy Group offices. Table 3 summarizes the installed data points and sensors. The "ID" column in the table correlates the sensors to their installation location on the water schematic heater shown in Figure 6. Manual dampers are shown, depicting the dual flow paths on both the evaporator inlet and outlet sides. On the inlet side, air from either outdoors or the interior space can be selected. On the outlet side, the cooled air can either be directed indoors (during the summer season) or direct outdoors (during the winter season ${ }^{6}$ ). The indoor temperature/resistance heat (RH) sensor was located adjacent to the first floor indoor HVAC thermostat and the outdoor sensor with gill radiation shield was located on the north side of each home. In addition to installing power monitors to record total water heater energy use (and backup electric-resistance energy use for the HPWH), power monitors were installed on the two $\mathrm{AC}$ condensing units (or packaged heat pumps) at each site.

The programmable data logger was configured to capture data at multiple logging intervals, as described below. Onboard data logger memory is sufficient to store more than one week of data, so any short-term communication losses do not interrupt the data stream. Data storage cards were also installed in the data logger to provide added data backup capability.

The flow meter was scanned continuously to detect the initiation of a hot water draw event. Once flow is detected, the data logger initiates 4-second interval logging of water flow, as well as water heater inlet and outlet water temperatures. Equation 1 describes the energy calculation performed on the 4-second interval when flow is occurring. This high-resolution logging

\footnotetext{
${ }^{5}$ In milder climates, the HPWH benefit on space cooling energy use is harder to determine as the occupant's variable use of natural ventilation impacts how much benefit actually offsets space cooling usage.

${ }^{6}$ This study was limited to summer-only monitoring, but additional utility funding allowed the work to continue through the 2014-15 winter.
} 
continues for the duration of the hot water draw event. In addition, a second logging schedule was programmed to occur on a fixed 15-minute interval. This fixed interval logging included:

- Average indoor and outdoor dry bulb temperature and RH

- Average HPWH inlet and leaving air temperature and RH during operation

- HPWH electrical energy consumption (total unit and electric resistance only)

- $\mathrm{AC}$ (or packaged heat pump) average demand during the 15-minute interval

- HPWH and cooling system run fraction during the 15-minute interval

- Total volume of hot water flow and energy delivered (as defined in Equation 1).

$$
\text { Equation 1: } \left.\quad Q \boldsymbol{Q} i=8.33 \frac{l b}{g a l} * 1.0 \frac{B t u}{l b-{ }^{\circ} \boldsymbol{F}} * V_{i} *\left(T H_{i}-T L_{i}\right) * 0.001\right)
$$

where,

$\mathrm{Q}_{\mathrm{i}} \quad=$ energy content of water flow during four second interval " $\boldsymbol{i}$ ” (kBtu/4 seconds)

$\mathrm{V}_{\mathrm{i}} \quad=$ hot water flow volume during four second interval “ $\boldsymbol{i}$ ” (gallons/4 seconds)

$\mathrm{TH}_{\mathrm{i}}=$ temperature leaving the water heater in $\left({ }^{\circ} \mathrm{F}\right)$ during interval " $\boldsymbol{i}$ "

$\mathrm{TL}_{\mathrm{i}}=$ temperature entering the water heater in $\left({ }^{\circ} \mathrm{F}\right)$ during interval " $i$ "

Table 3. Monitoring Sensor Specifications

\begin{tabular}{|c|c|c|c|c|c|c|}
\hline Type & Application & ID & Mfg/Model & Signal & Span & Accuracy \\
\hline $\begin{array}{l}\text { Duct } \\
\text { temp./RH }\end{array}$ & $\begin{array}{l}\text { HPWH inlet } \\
\text { and outlet air }\end{array}$ & $\begin{array}{l}5,6 \\
7,8\end{array}$ & $\begin{array}{l}\text { Vaisala } \\
\text { HMD42 }\end{array}$ & $4-20 \mathrm{~mA}$ & $\begin{array}{l}-4 \text { to } 140^{\circ} \mathrm{F} \\
0-100 \%\end{array}$ & $\begin{array}{l} \pm 0.54{ }^{\circ} \mathrm{F} @ 68^{\circ} \mathrm{F} \\
\pm 3 \% \mathrm{RH}(30-70 \%)\end{array}$ \\
\hline $\begin{array}{l}\text { Wall mount } \\
\text { temp./RH }\end{array}$ & $\begin{array}{l}\text { Indoor air } \\
\text { temperature } \\
\text { and } \mathrm{RH}\end{array}$ & $\mathrm{n} / \mathrm{a}$ & $\begin{array}{l}\text { Vaisala } \\
\text { HMW82 }\end{array}$ & $4-20 \mathrm{~mA}$ & $\begin{array}{l}-4 \text { to } 140^{\circ} \mathrm{F} \\
0-100 \%\end{array}$ & $\begin{array}{l} \pm 0.54{ }^{\circ} \mathrm{F} @ 68^{\circ} \mathrm{F} \\
\pm 3 \% \mathrm{RH}(30-70 \%)\end{array}$ \\
\hline $\begin{array}{l}\text { Outdoor air } \\
\text { temp./RH }\end{array}$ & $\begin{array}{l}\text { Shielded } \\
\text { outdoor sensor }\end{array}$ & $\mathrm{n} / \mathrm{a}$ & $\begin{array}{l}\text { RM Young } \\
\text { model } 41372\end{array}$ & 4-20 mA & $\begin{array}{l}14 \text { to } 140^{\circ} \mathrm{F} \\
0-100 \%\end{array}$ & $\begin{array}{l} \pm 0.54{ }^{\circ} \mathrm{F} \\
\pm 3 \% \mathrm{RH}(10-90 \%)\end{array}$ \\
\hline $\begin{array}{l}\text { Power } \\
\text { monitors }\end{array}$ & $\begin{array}{l}\text { HPWH and AC } \\
\text { power }\end{array}$ & $\begin{array}{l}11 \\
12\end{array}$ & $\begin{array}{l}\text { Wattnode/ } \\
\text { WNA-1-P- } \\
240-P\end{array}$ & pulse & $0-30 A$ & $\pm 1.5 \%$ of reading \\
\hline $\begin{array}{l}\text { Flow } \\
\text { meter }\end{array}$ & $\begin{array}{l}\text { Flow to water } \\
\text { heater (cold) }\end{array}$ & 15 & $\begin{array}{l}\text { Onicon F- } \\
1300\end{array}$ & $\begin{array}{l}\text { Frequency } \\
\text { output }\end{array}$ & $\mathrm{n} / \mathrm{a}$ & $\begin{array}{l} \pm 2 \% \text { of reading } \\
\text { from } .8 \text { to } 38 \mathrm{gpm}\end{array}$ \\
\hline $\begin{array}{l}\text { Immersion } \\
\text { thermocouple }\end{array}$ & $\begin{array}{l}\text { Hot and cold } \\
\text { side temps }\end{array}$ & 9,10 & $\begin{array}{l}\text { Gordon } \\
\text { 20CTOUH }\end{array}$ & $\mathrm{mV}$ & $\mathrm{n} / \mathrm{a}$ & $\pm 0.9^{\circ} \mathrm{F}$ \\
\hline
\end{tabular}




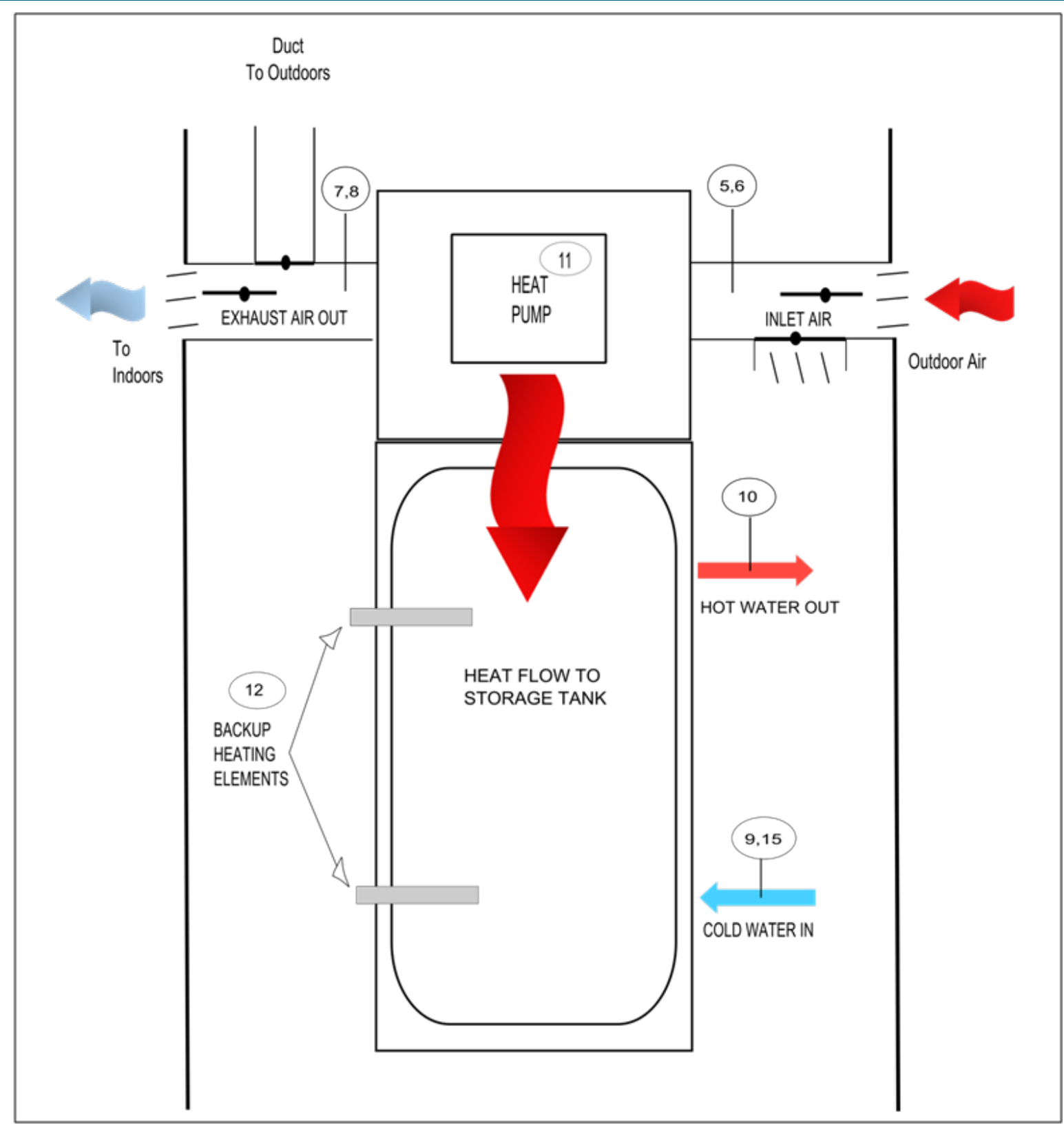

Figure 6. Schematic of ducted HPWH configuration and monitoring points

HPWH efficiency calculations were completed on a daily basis. Although these calculations could be completed on either shorter or longer time scales, the daily COP calculation was chosen as a reasonable performance metric to document performance and influences due to hot water load variations. A shorter COP calculation procedure is challenging as HPWH operation is largely disconnected from many hot water load events. For example, a two-hour COP calculation metric may exhibit hot water loads, but no HPWH heating operation, or vice versa. Longer intervals would smooth out any effects that may influence system performance, but also tend to smooth out any performance variability. Equation 2 presents the daily COP calculation used in this study. Note that the calculated COP is based on the sum of the daily energy leaving the hot 
water tank (i.e., recovery load), not the input to the tank. In a lab setting, a vertical stalk of thermocouples is commonly installed in the tank to record tank temperature at different points in the tank, allowing for calculation of an average tank temperature.

\section{Equation 2: $\quad$ Daily Efficiency $(C O P)=\left(\sum_{i=1}^{m} Q i \div \sum_{j=1}^{96} E W H j\right) \div 3.412$}

where,

$\mathrm{Q}_{\mathrm{i}}$

$\mathrm{EWH}_{\mathrm{j}}(\mathrm{kWh})$

$" i=1$ to $m "$

$" \mathrm{j}=1$ to $96 "$
$=$ water heater energy delivered for interval " $i$ "

= water heater energy electrical consumed for interval " $j$ ”

$=$ " $\mathrm{m}$ " is the number of four second intervals/day with flow

$=96$ fifteen minute interval data records per day

\subsection{Uncertainty of Calculations}

Uncertainties ${ }^{7}$ in the measured variables are published in instrument technical specifications and are presented below in Table 4. Assuming the uncertainties of the measured variables are not correlated, the total uncertainty $\left(U_{R}\right)$ in the system variable can be approximated using the delta method, as shown below.

$$
\text { Equation 3: } \quad U_{R}=\sqrt{\sum\left(\frac{\partial R}{\partial x_{i}} u_{x_{i}}\right)^{2}}
$$

Where:

$\frac{\partial R}{\partial x_{i}}$

$\overline{\partial x_{i}}$ is the sensitivity coefficient [partial derivative of Performance Metric, in this case R, with respect to measured variable $\left.\left(\mathrm{x}_{i}\right)\right]^{8}$ and ${ }^{u_{x_{i}}}$ is the uncertainty of the measured variable.

\footnotetext{
${ }^{7}$ As used in this analysis "uncertainty" is defined as half the width of a confidence interval or a standard deviation around a measurement value.

${ }^{8}$ The partial derivatives depend on the values of the lower level variables and so (typically) unlike the uncertainties of the lower level measurements, it depends on the value of "x." The resulting sensitivity coefficient can change over the range encountered. This can result in situations in which one of the measured variables is the critical one within part of the operating range; however, another becomes more critical in another range.
} 
Table 4. Instrument Uncertainties

\begin{tabular}{|lc|}
\hline Instrument & Uncertainty $\left(\mathrm{u} \mathrm{X}_{\mathrm{i}}\right)$ \\
\hline Immersion Thermocouple & $\pm 0.9^{\circ} \mathrm{F}$ \\
Immersion Flowmeter & $\pm 2.0 \%$ \\
Power Transducer & $\pm 1.5 \%$ \\
\hline
\end{tabular}

In this study, uncertainty is determined via the Engineering Equation Solver (EES) ${ }^{9}$. The EES helps determine an error percentage for the metric of interest over a known range of values. This maximum percentage of error at the smaller timescale was then applied to the larger daily sums.

The DHW heat flow relationship, as defined in Equation 1, results in the " $Q$ " uncertainty as shown in Equation 4.

$$
\text { Equation 4. } \quad \boldsymbol{u} Q= \pm\left(\sqrt{\left(\frac{\delta Q}{\delta V} * u_{V}\right)^{2}+\left(\frac{\delta Q}{\delta T h} * u_{T h}\right)^{2}+\left(\frac{\delta Q}{\delta T l} * u_{T l}\right)^{2}}\right)
$$

Normal DHW events represent a range of flow rates, inlet and outlet water conditions, and Table 5 characterizes the uncertainty for a range of temperature conditions and flow rates. Hot water temperature, $\mathrm{T}_{\mathrm{h}}$, is normally in the $125^{\circ} \mathrm{F}$ range, although lower temperatures occur under shortduration, high-load events. Cold water temperature, $\mathrm{T}_{1}$, varies seasonally, with much of California conditions falling in the $55-75^{\circ} \mathrm{F}$ range. Flow rates depend on a wide range of factors and vary from less than one tenth of a gallon per minute to 3 to $4 \mathrm{gpm}$. The vast majority of hot water events over the course of a year will fall in a 1.0 to $1.5 \mathrm{gpm}$ window.

In the case of heat flow, the uncertainties over the range of expected values indicate a maximum uncertainty of $4.1 \%$.

COP calculations were completed on a daily basis. This involved the summation of the water heater energy flows over the course of the day, divided by the HPWH energy input (as defined in Equation 2). Equation 5 reflects the COP uncertainty in terms of energy flow (Q) and the electrical energy uncertainty $(\mathrm{W})$.

$$
\text { Equation 5. } \quad \boldsymbol{u C O P}= \pm\left(\sqrt{\left(\frac{\delta C O P}{\delta Q} * u_{Q}\right)^{2}+\left(\frac{\delta C O P}{\delta W} * u_{W}\right)^{2}}\right)
$$

To assess typical COP uncertainties, two representative cases were evaluated based on ranges identified from the monitoring data. A low-usage day with a recovery load of 10,000 Btu/day and $1.24 \mathrm{kWh}$ consumption and a high-usage day with a recovery load of 50,000 Btu/day and $6.37 \mathrm{kWh}$ consumption. The resulting COP uncertainty ranged from 3.9-4.3\% for the two cases.

${ }^{9}$ http://www.fchart.com/ees/ 
Table 5. Heat Flow Uncertainty Calculations

\begin{tabular}{|cccccc|}
\hline $\mathbf{T}_{\mathbf{h}}$ & $\mathbf{T}_{\mathbf{I}}$ & $\mathbf{g p m}$ & $\mathbf{Q}$ (Btu) & $\mathbf{u Q}$ (士Btu) & $\mathbf{u Q \% / Q}$ \\
\hline 130 & 55 & 0.5 & 312.4 & 8.6 & $2.7 \%$ \\
\hline 130 & 55 & 1.5 & 937.1 & 25.8 & $2.7 \%$ \\
\hline 130 & 55 & 2.5 & 1562.0 & 42.9 & $2.7 \%$ \\
\hline 130 & 65 & 0.5 & 270.7 & 8.0 & $3.0 \%$ \\
\hline 130 & 65 & 1.5 & 812.2 & 24.0 & $3.0 \%$ \\
\hline 130 & 65 & 2.5 & 1354.0 & 40.1 & $3.0 \%$ \\
\hline 130 & 75 & 0.5 & 229.0 & 7.5 & $3.3 \%$ \\
\hline 130 & 75 & 1.5 & 687.2 & 22.4 & $3.3 \%$ \\
\hline 130 & 75 & 2.5 & 1144.9 & 37.3 & $3.3 \%$ \\
\hline 115 & 55 & 0.5 & 249.9 & 7.7 & $3.1 \%$ \\
\hline 115 & 55 & 1.5 & 749.7 & 23.2 & $3.1 \%$ \\
\hline 115 & 55 & 2.5 & 1250.0 & 38.6 & $3.1 \%$ \\
115 & 65 & 0.5 & 208.3 & 7.2 & $3.5 \%$ \\
115 & 65 & 1.5 & 624.8 & 21.6 & $3.5 \%$ \\
115 & 65 & 2.5 & 1041.0 & 36.1 & $3.5 \%$ \\
\hline 115 & 75 & 0.5 & 166.6 & 6.8 & $4.1 \%$ \\
\hline 115 & 75 & 1.5 & 499.8 & 20.3 & $4.1 \%$ \\
\hline 115 & 75 & 2.5 & 832.9 & 33.8 & $4.1 \%$ \\
\hline
\end{tabular}

\subsection{Climate Influences}

The Redding location was selected as a preferred field test location for two primary reasons: A local utility with significant electric-resistance water heating market share, and a very hot climate (2003 cooling degree days at base 65) that provides for a more suitable testing location to assess summer space-cooling benefits derived from utilizing the HPWH cooled evaporator leaving air. Redding is located 160 miles north of Sacramento near the northern end of the Central Valley of California. Summer weather conditions in this area are more extreme than the Sacramento area, since any moderating coastal influence is mitigated. Figure 7 presents daily maximum, minimum, and average outdoor temperatures during the period of monitoring from May 1, 2014, through September 14, 2014. Extended periods with high temperatures exceeding $95^{\circ} \mathrm{F}$ and lows exceeding $65^{\circ} \mathrm{F}$ provide a good testing framework for consistent cooling operation and ability to utilize HPWH evaporator leaving air.

The City of Redding has both surface water and groundwater as part of its municipal water service. The Sacramento River (fed by upstream Lake Shasta) and nearby Whiskeytown Lake provide $74 \%$ of the Redding municipal water supply, while the remaining $26 \%$ is groundwater that comes from 16 city wells. Both surface water sources provide relatively cold water supplies generated largely from snowmelt. This combination of surface and ground water resulted in interesting monitored cold water temperature variations at the two sites. Figure 8 plots monthly average recorded temperatures during periods when cold water is flowing into the water heater. Site 1 shows average monthly cold water temperatures, as much as $15^{\circ} \mathrm{F}$ cooler than Site 2, likely due to the local source of potable water. Site 2 also demonstrated an interesting solar heating effect. On summer days with both early morning hot water draws and draws around 5 p.m., 
monitored cold water temperatures during the later hours would average $7-8^{\circ} \mathrm{F}$ higher than in the morning. Our hypothesis is that the cold water supply line to the house is under the driveway, which heats up considerably in the hot Redding summer climate.

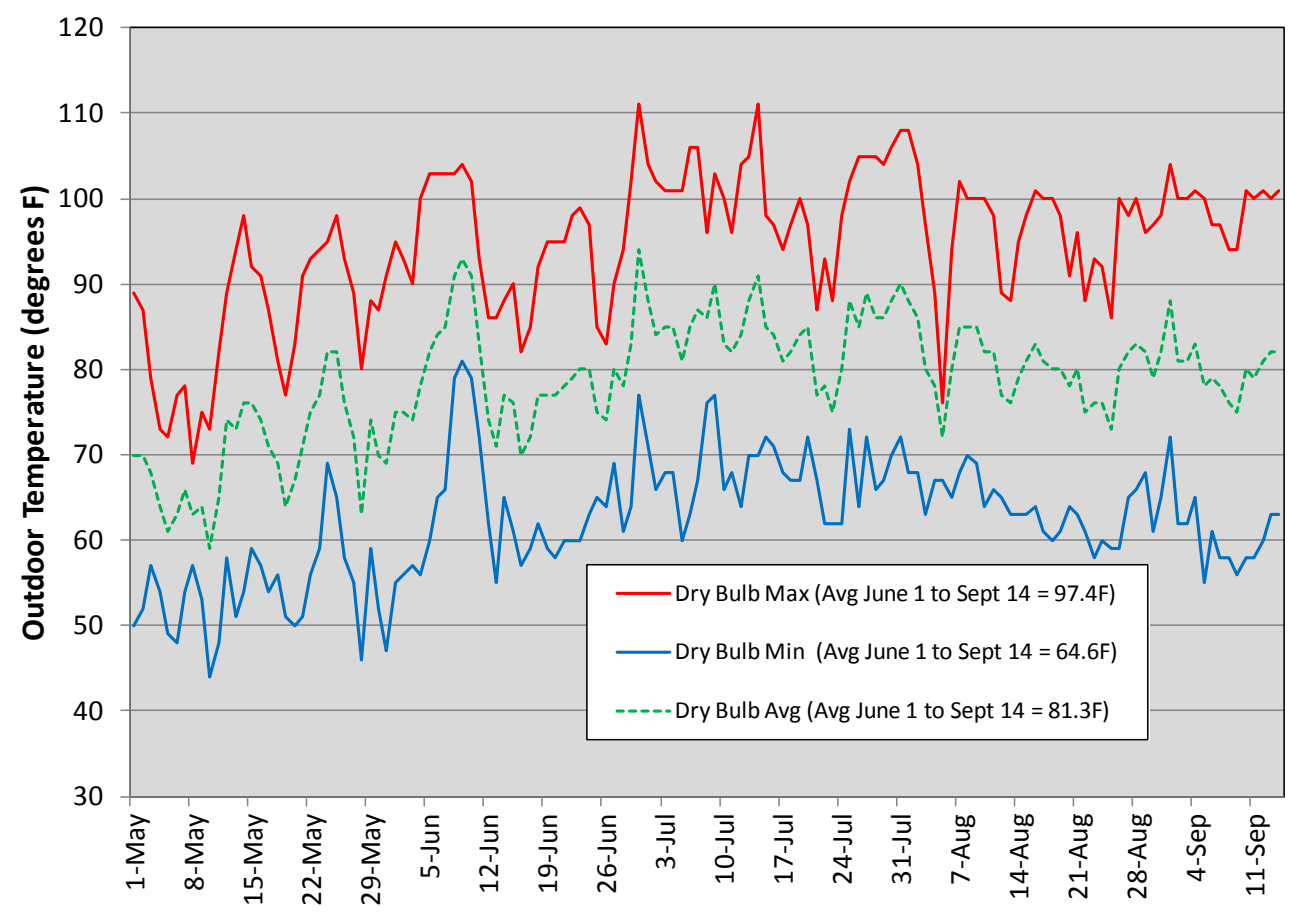

Figure 7. Official National Weather Service daily recorded Redding temperatures

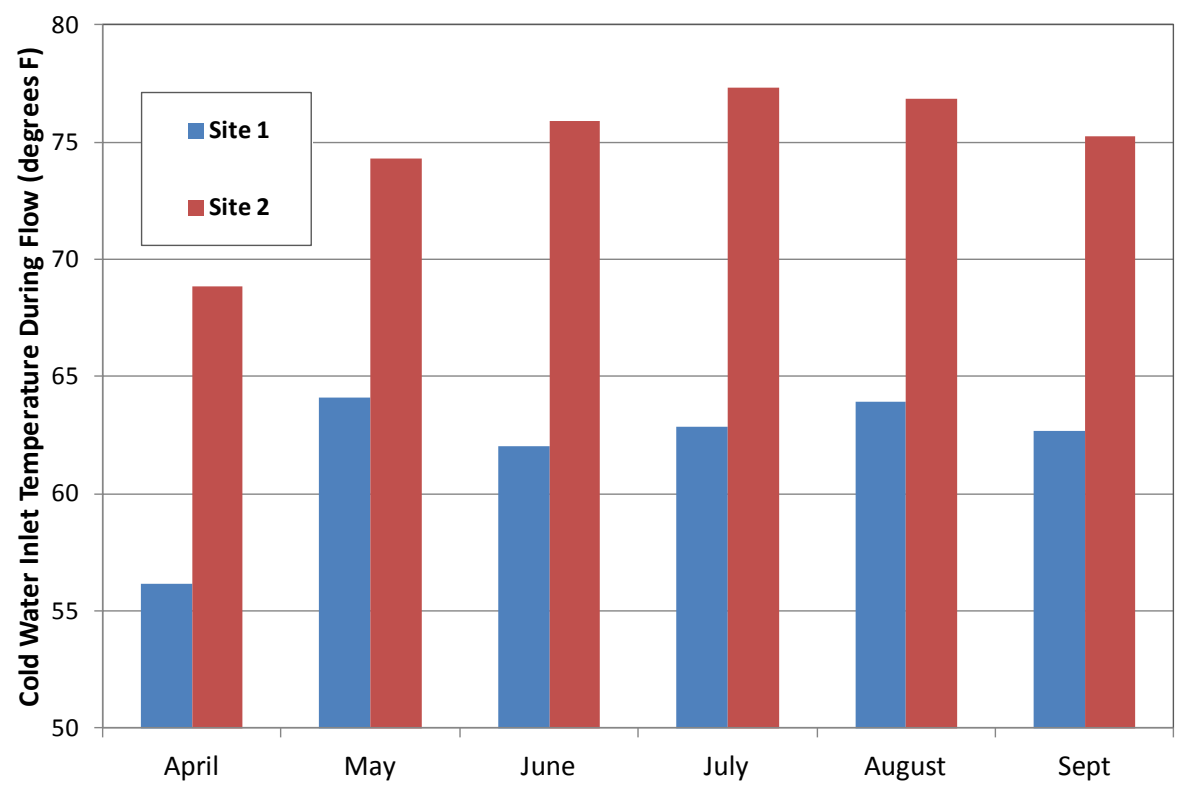

Figure 8. Water heater cold water inlet temperatures by site 


\section{Results}

\subsection{Baseline Water Heater Monitoring}

Monitoring equipment was installed on April 23 and April 24, 2014, at the two sites. Baseline electric storage water heating data were desired to document the performance and energy usage of the conventional system type, as well as to troubleshoot any startup issues with the monitoring system. At Site 2 (with six residents), the inability of the existing 50-gallon storage water heater to consistently satisfy the hot water loads was immediately confirmed by monitoring data. Figure 9 plots 4-second interval hot water temperatures and hot water flow rates over a day-and-a-half period $^{10}$. The number of hot water tank "run outs" is evident on several occasions over this period of time, with the lowest observed hot water supply temperature under $90^{\circ} \mathrm{F}$. Figure 10 plots daily electric water heater energy use versus gallon-per-day consumption for the two sites. Both sites shows the anticipated well-correlated hot water energy use versus load, with Site 2 showing distinctly lower electrical consumption per gallon of hot water, likely due to a combination of warmer inlet (cold) water temperatures and the common hot water tank run outs.

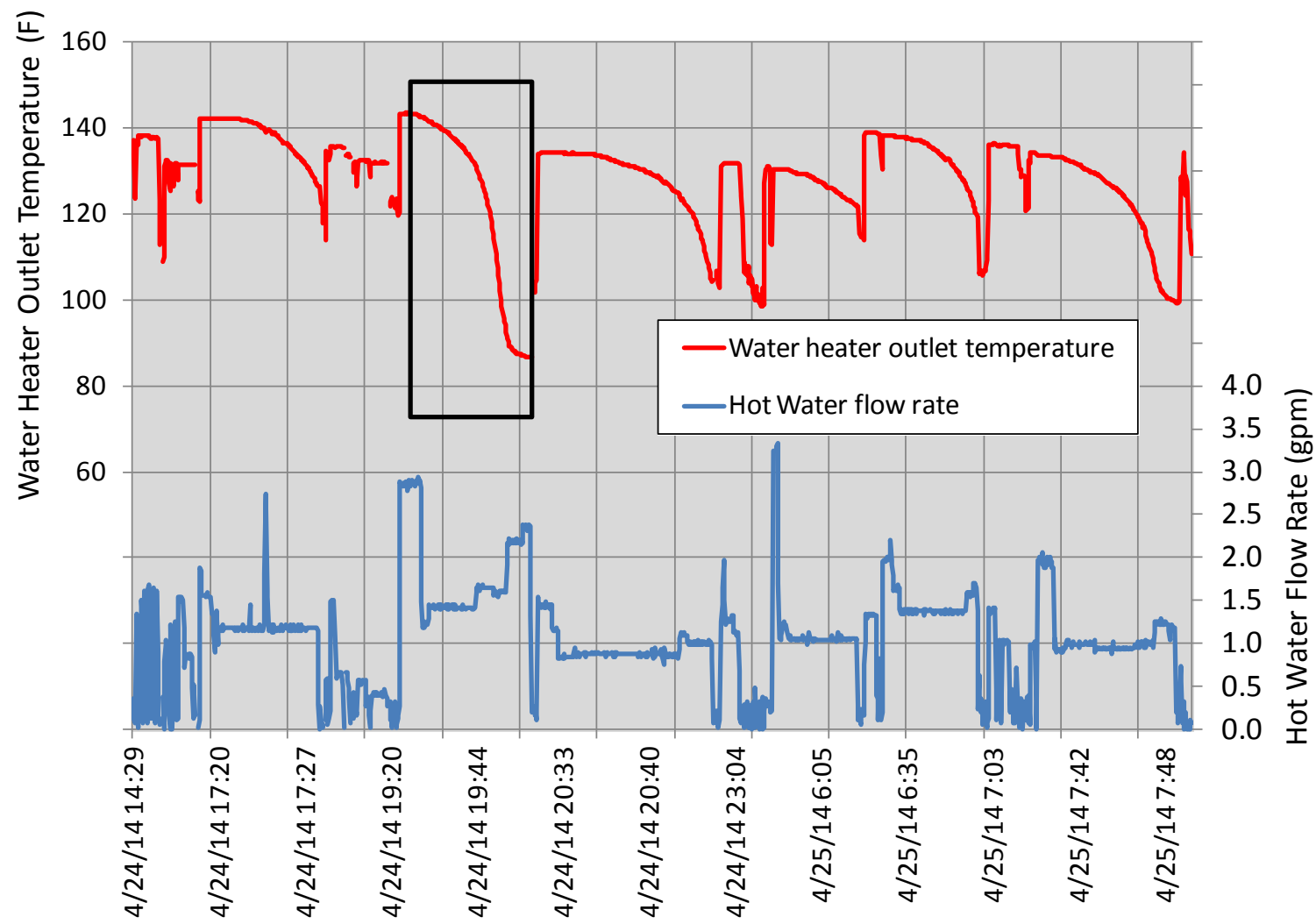

Figure 9. Sample Site 2 electric water heater baseline monitoring

\footnotetext{
${ }^{10}$ Note: Only data with flow is show.
} 


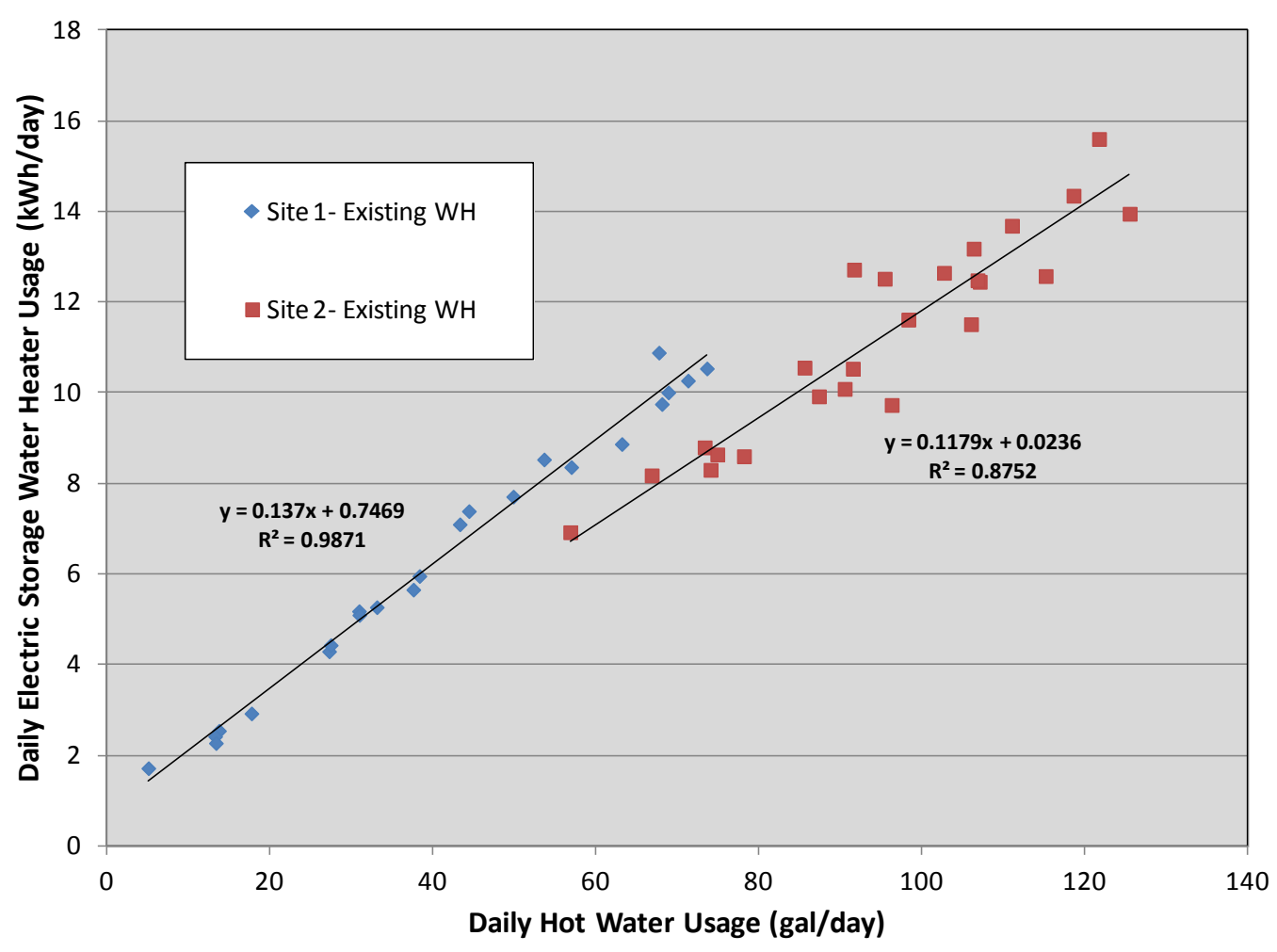

Figure 10. Baseline electric water heater energy use vs. load

\subsection{HPWH System Commissioning and Operational Issues}

The HPWHs, minus the ducting kits, were installed on May 22 at Site 1 and May 23 at Site 2. After repeated interactions with the homeowners and the installing contractor (Energy Docs), the decision was made to not install a ducting kit at Site 1 since the only aesthetically feasible approach to running ducting from the water heater location to both outdoors and a central interior location would have required penetrating masonry block walls at two locations. From the viewpoint of the homeowner, this approach was not acceptable, since they were uncertain whether they would want the ducting to remain after the end of monitoring. Based on the owner's input, the decision was made to drop the ducting kit implementation at Site 1.

After installation, the units were immediately operated in HPWH "Auto" mode ${ }^{11}$ for initial shakedown monitoring at a setpoint of $125^{\circ} \mathrm{F}^{12}$. The ducting kit for Site 2 was not originally in stock with the manufacturer and had to be shipped as part of a larger order from China. The kits did not arrive until late-June and was installed on June 30. The ducting at Site 2 was configured to provide HPWH evaporator entering air from either the laundry room or outdoors, and exhaust evaporator leaving air to the kitchen area or outdoors.

Another minor issue occurred related to the HPWH control boards. During the course of the summer monitoring, the intent was to collect a period of electric-resistance-only operating data

\footnotetext{
${ }^{11}$ Auto mode provides for heat pump priority with electric-resistance backup when the unit cannot adequately maintain tank conditions.

${ }^{12} 125^{\circ} \mathrm{F}$ setpoint was maintained throughout the summer monitoring at both sites.
} 
with the HPWH ${ }^{13}$ to provide mid-summer documentation of performance to supplement the lateApril to mid-May existing water heater monitoring. During the implementation of the resistanceonly mode of operation on the Site 1 unit, monitoring indicated that the control change did not affect operation. The manufacturer contact was notified and reported that there was apparently a control issue that required a new control board. The boards were shipped from China, causing an additional delay in testing this mode. Once resolved, a 10-day testing period in electric-resistance mode was completed at Site 1; however, no testing was completed at Site 2 . With the exception of this identified issue, both units operated reliably for the duration of the summer.

Figure 11 documents the installed unit at Site 1. Figure 12 shows the Site 2 unit installed in the laundry room with horizontal ducting penetrating the laundry room cabinet (to the left) to outdoors, and vertical ducting entering the attic to serve either the new kitchen duct (see new supply grille on the upper right of Figure 13) or dump evaporator leaving air into the attic.

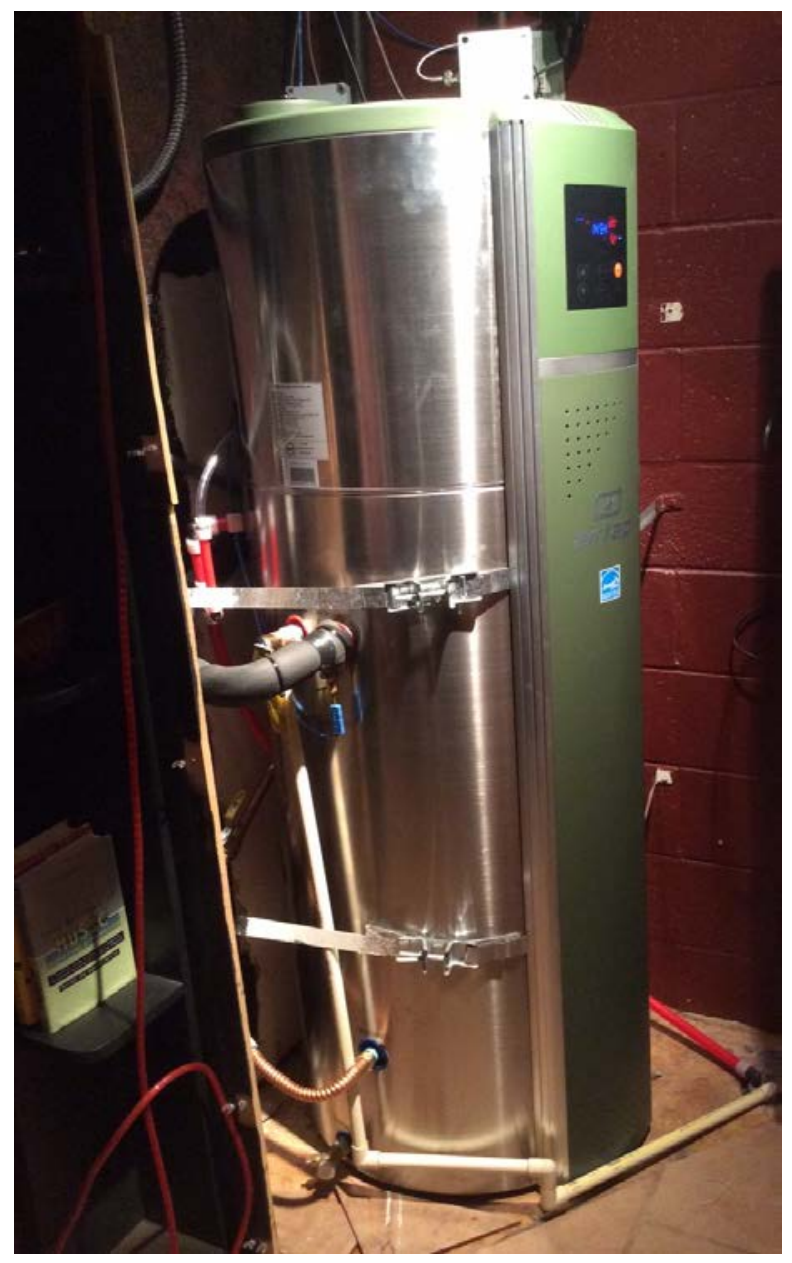

Figure 11. Installed HPWH at Site 1

Photo credit: M. MacFarland, reprinted with permission

\footnotetext{
${ }^{13}$ The unit's manual indicates the capability to set electric-resistance operation for up to 999 hours, at which time the unit will revert to heat pump operation.
} 


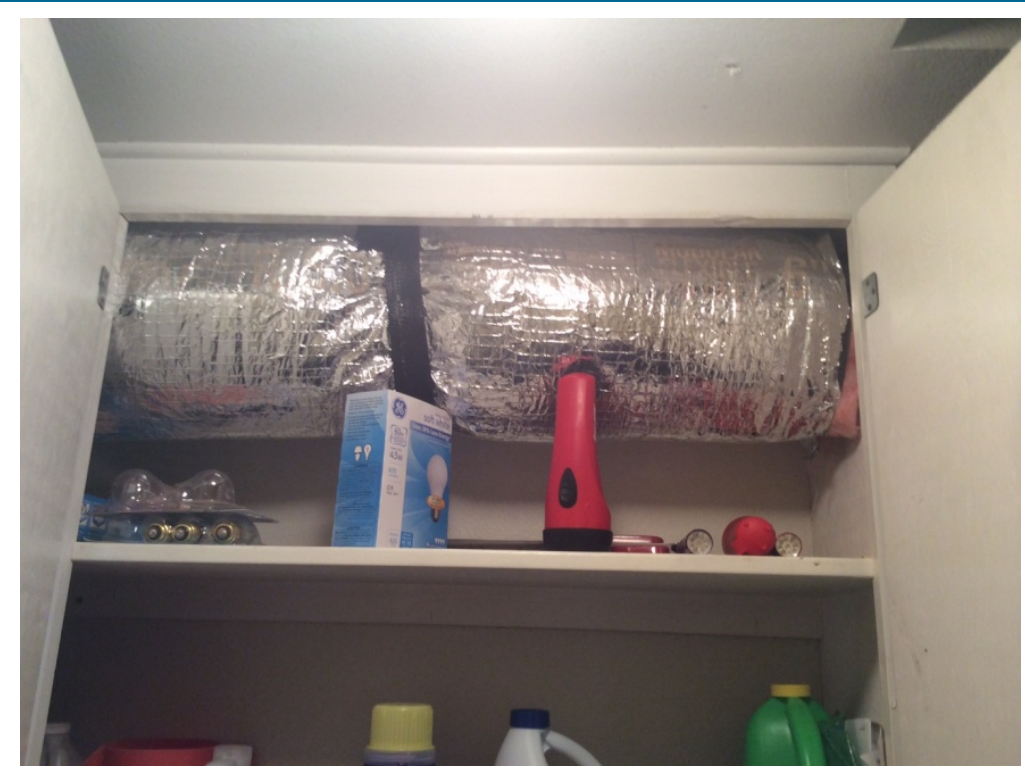

Figure 12. Site 2 ducting run to outdoors

Photo credit: M. MacFarland, reprinted with permission

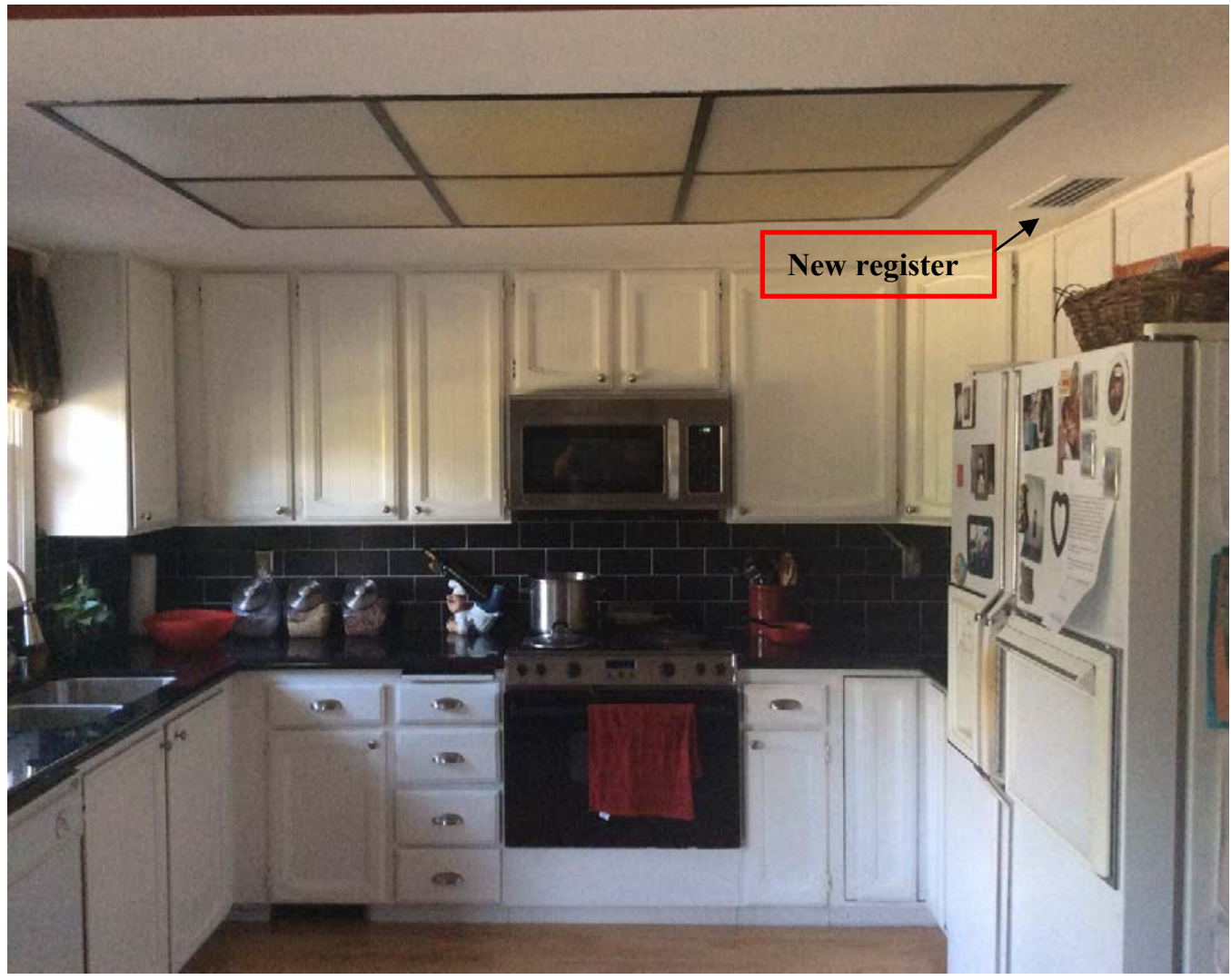

Figure 13. Site 2, HPWH evaporator leaving air discharge to kitchen

Photo credit: M. MacFarland, reprinted with permission 


\subsection{Monitored HPWH Performance}

The HPWHs were installed without ducting kits on May 22 at Site 1 and on May 23 at Site 2. The units were set up in "hybrid" mode, allowing for simultaneous compressor and back-up electric element operation, if the controls determined that the tank setpoint was not being adequately met by the compressor operation. Figure 14 plots five sample water heating cycles to characterize the timing, duration, and profile of individual days of water heating operation at the two sites. As one would expect with a compressor-based system, the demand is generally lowest at the start of the cycle and increases as the tank temperature increases during the typical 2.5- to 4-hour heating cycle. The red line shows a dip shortly before midnight as hot water loads during the recovery cycle drive the tank temperature down, reducing the system condensing temperature. The purple line shows a rare summer case where electric-resistance operation is required to maintain adequate tank temperatures during the recovery cycle. Over the full summer monitoring period, the electric-resistance heating represented only 4-7\% of total unit consumption, with the higher value associated with Site 1 (smaller 66-gallon tank) where hot water loads for the two person household appeared to be more variable day-to-day, as well as more intense in duration.

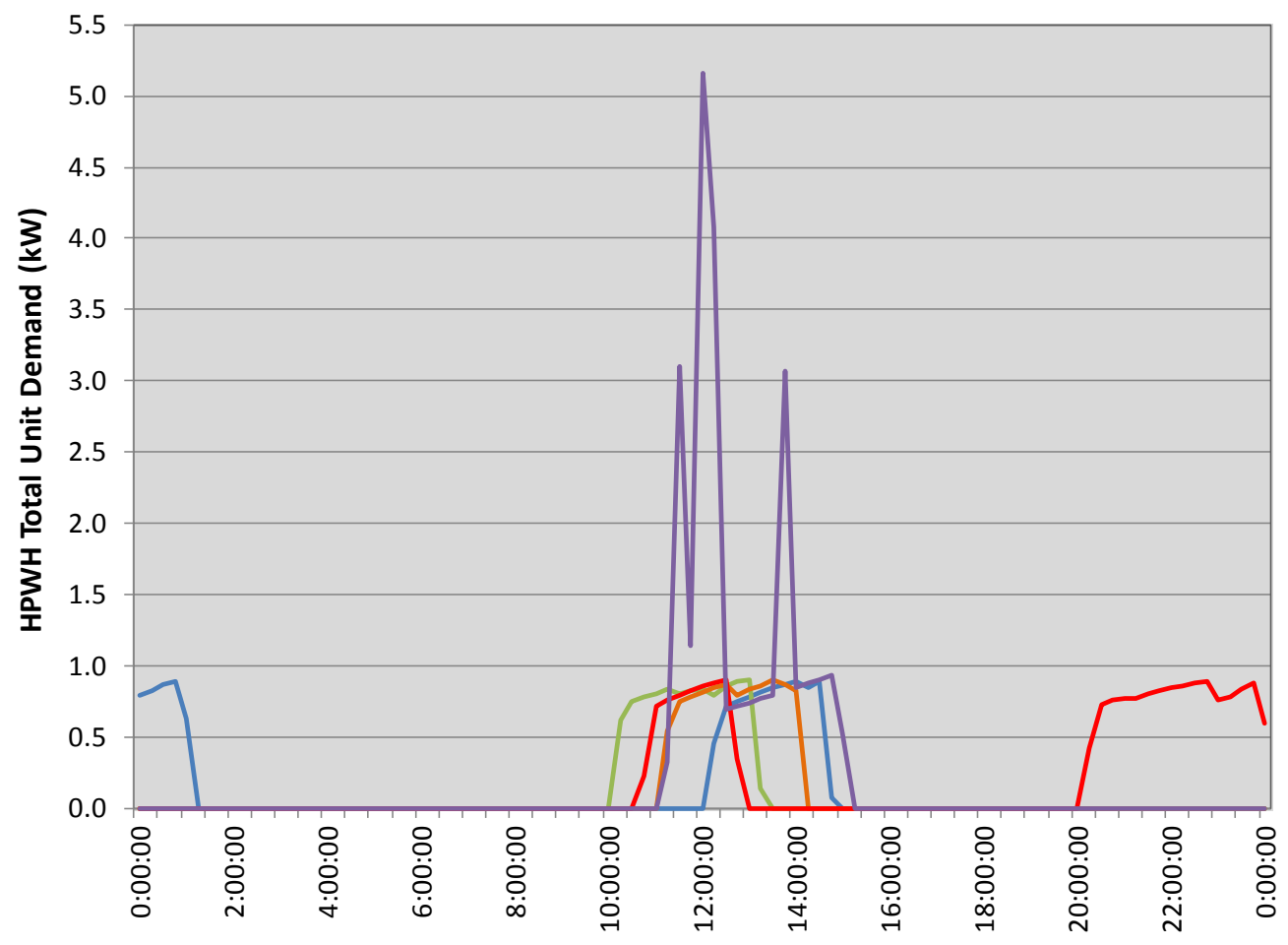

Figure 14. Sample HPWH demand profiles (15 minute interval data)

Figure 15 plots the observed average HPWH demand profile during the June 6 through September 23 period. With peak observed "compressor-only" unit demands in the $0.9 \mathrm{~kW}$ range, the data suggests the maximum peak summer operating demand at a level $\sim 2 / 3$ lower than 0.9 $\mathrm{kW}$. Due to their relatively low early morning hot water consumption, Site 1 operation shifted to later in the day than Site 2. The shape of the profile provides a direct representation of when cooling is being provided to conditioned space and also contributing to peak air conditioning load reduction. With typical California electric utility peak demand periods in the 4 to 7 p.m. 
window, neither of the two sites demonstrated an optimal alignment with that time period in terms of cooling delivery to offset peak space cooling demand.

Average hot water consumption from May 23 through September 14 averaged 44.4 gallons per day (gpd) for Site 1 and $66.9 \mathrm{gpd}$ for Site 2. Although Site 2 has higher usage, Site 1 consumption (nominaly two occupants) is roughly double that of Site 2 (nominally six occupants) on a per-capita basis. The 11.1 to 22.2 gpd per-person consumption reflects not only the colder inlet water temperatures at Site 1, but also the level of variability that one can expect among households ${ }^{14}$.

Figure 16 plots daily HPWH energy use (excluding any resistance only modes of operation) as a function of daily hot water load. There are two points of interest: (1) the linear regression offset between Site 1 and 2 is consistent with that shown in the baseline monitoring (Figure 10) and likely due to consistently colder inlet water temperatures, and (2) the daily data are not as well correlated as Figure 10 due to occasional resistance heating usage spikes and end-of-day carryover effects that are more pronounced with the larger storage tank systems.

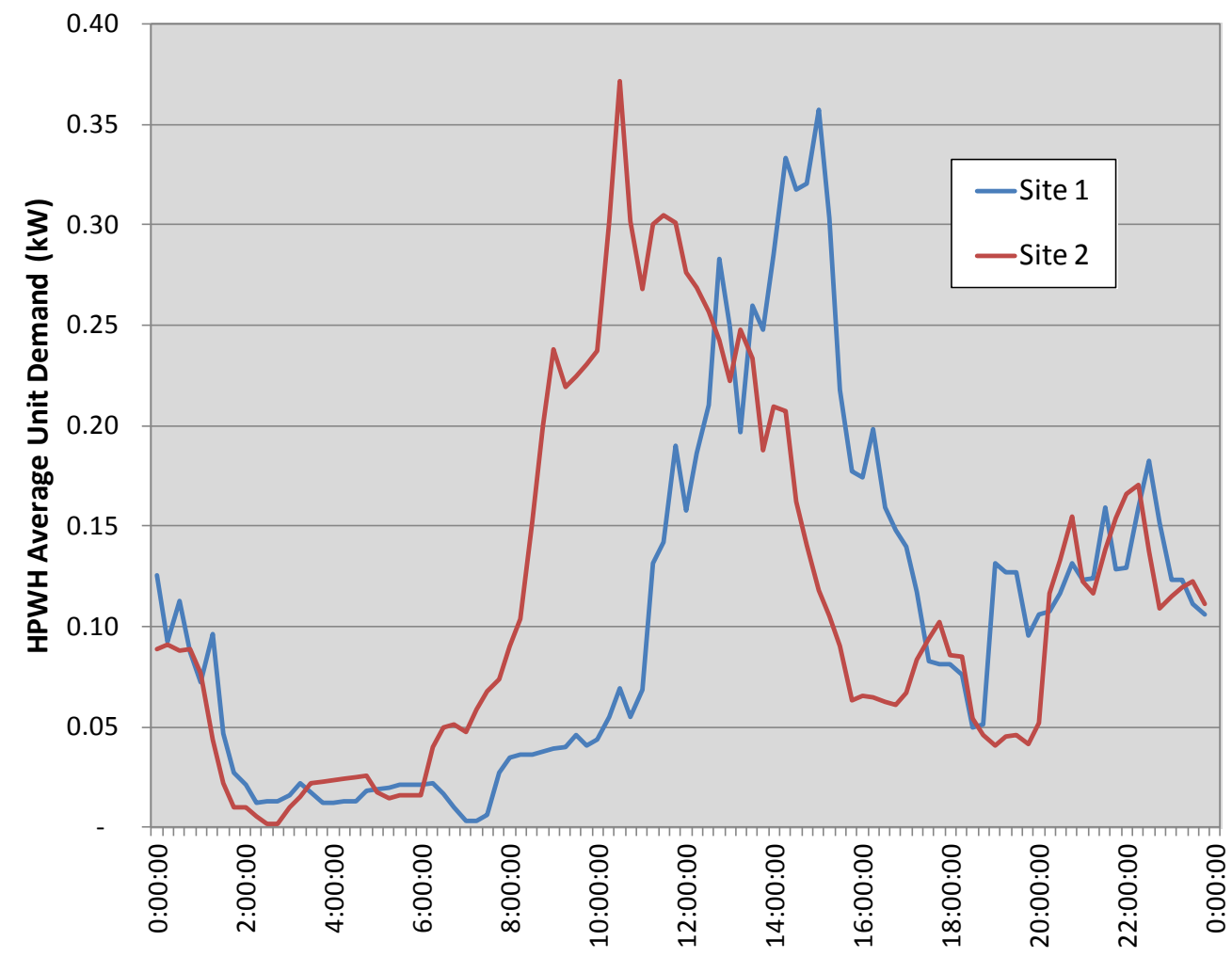

Figure 15. Average summer HPWH demand profile (15-minute interval data)

\footnotetext{
${ }^{14}$ Interestingly, the average of the two sites is very close to the $15.6 \mathrm{gpd} /$ person monitored hot water consumption documented in an 18-home California hot water monitoring study (Hoeschele and Weitzel 2013).
} 


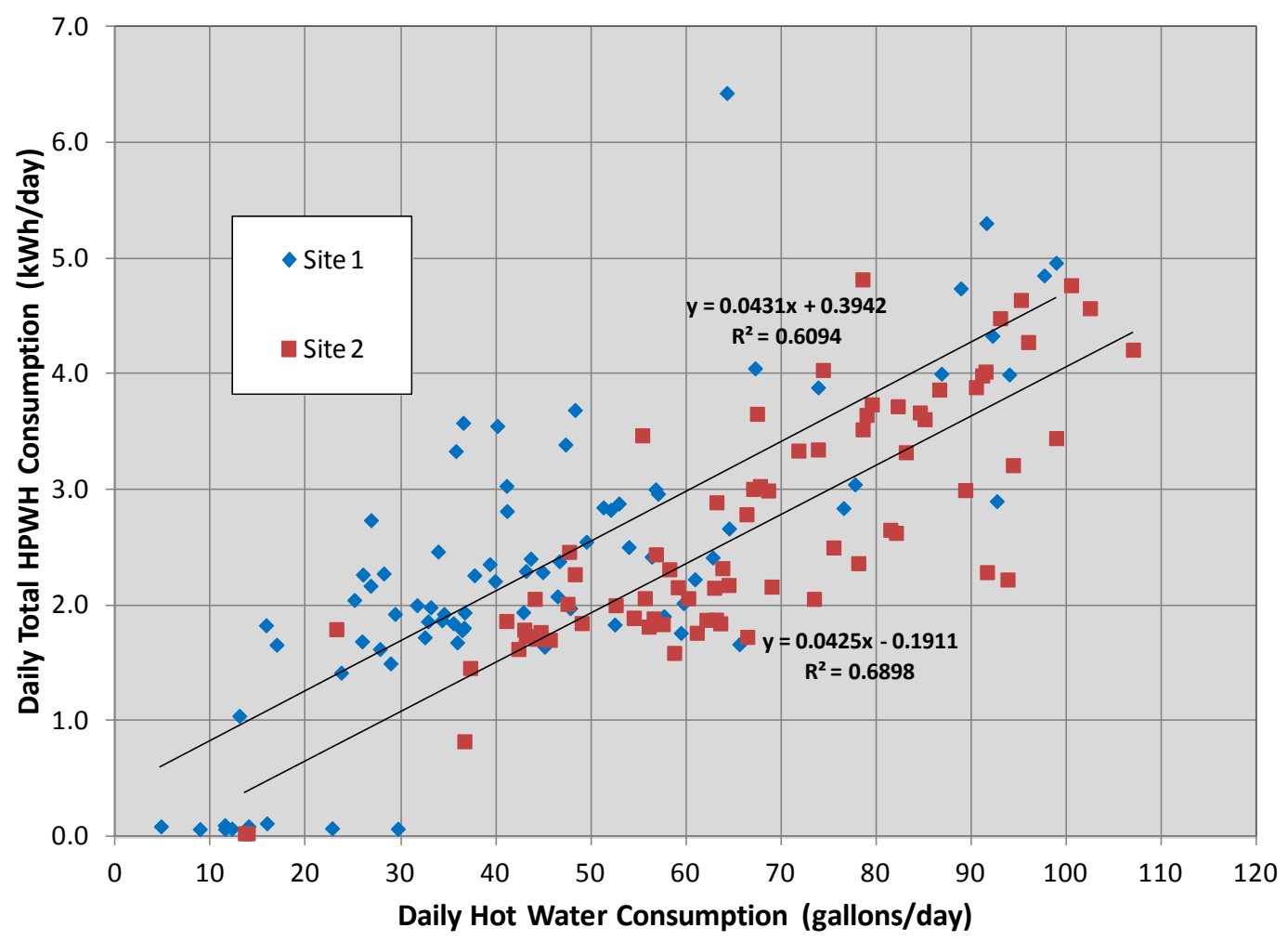

Figure 16. Daily HPWH energy use as a function of hot water use

Figure 17 plots both the electric RH and HPWH mode data that is shown in Figure 10 and Figure 16, as well as the Site 1 "HPWH (RH mode)" data for August 14-27. Slightly warmer cold water inlet temperatures and possibly reduced tank thermal losses contribute to the improved performance relative to the Site 1 "Existing WH" data. The performance advantage of the HPWH is clear at both sites, with typical daily energy savings in the $50-70 \%$ range for a given daily hot water consumption.

Figure 18 plots daily COP for both sites while the system was operating in the heat pump mode. A few daily COP values with no compressor operation and small amounts of energy delivered (i.e., recovery load on the water heater) generated high COPs that are not presented in the graph. Significant variations in daily COP are evident due to the timing of both hot water draws and heat pump operating cycles around the end of a day. For the time period monitored, recovery load weighted average COPs ranged from 2.60 at Site 1 to 2.85 at Site 2 . The Site 1 performance is slightly lower due to the greater use of electric-resistance heating ( $7 \%$ of summer consumption at Site 1 vs. only 4\% at Site 2). The smaller 66-gallon unit at Site 1 also exhibits a trend of decreasing efficiency at higher recovery loads, consistent with findings presented in the "CARB HPWH Measure and Strategy Guide” (Shapiro et al 2012). The few Site 2 (80-gallon HPWH) data points at higher loads appear less definitive in suggesting this trend. 


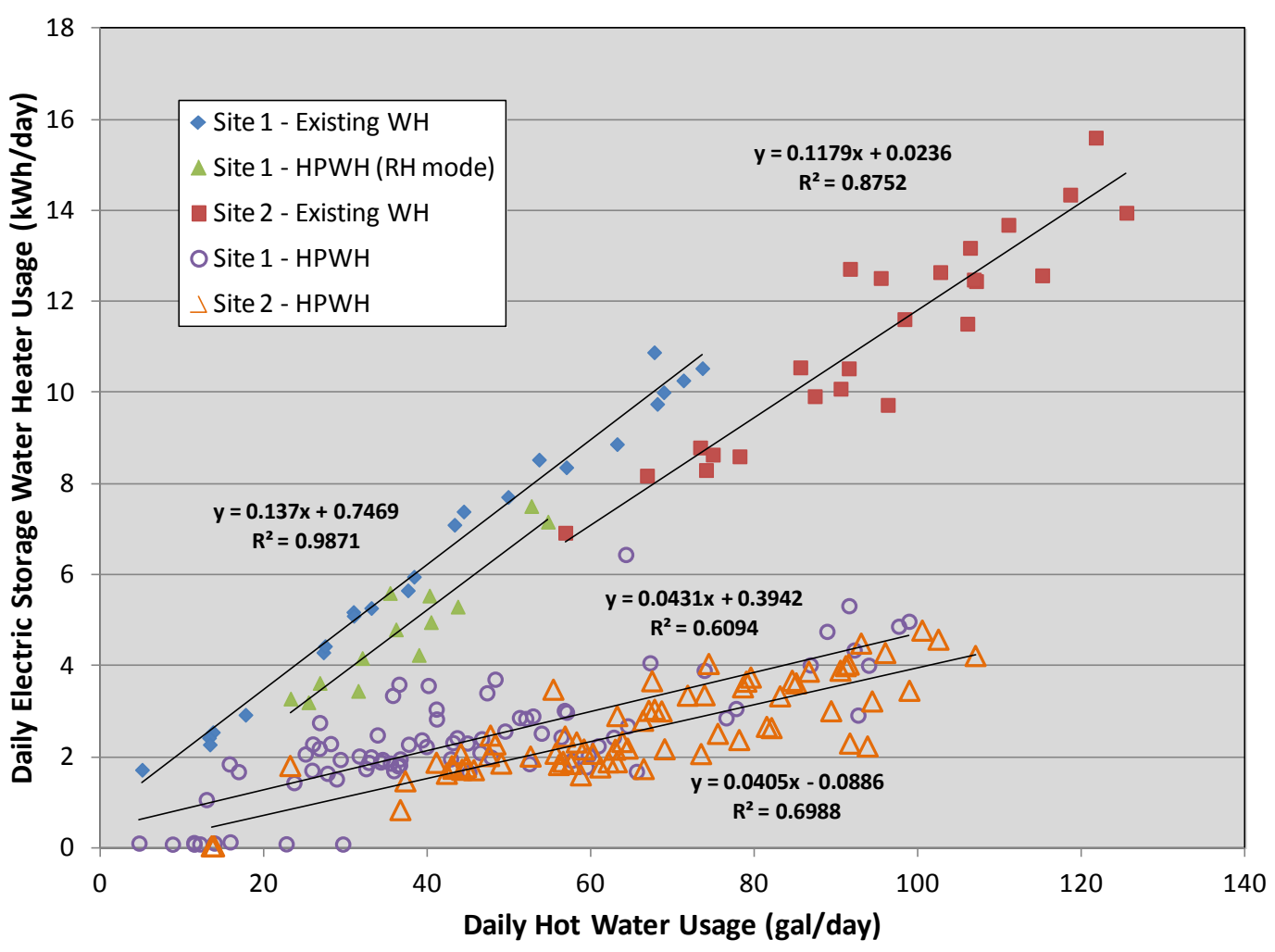

Figure 17. Comparison of electric-resistance and HPWH daily energy use

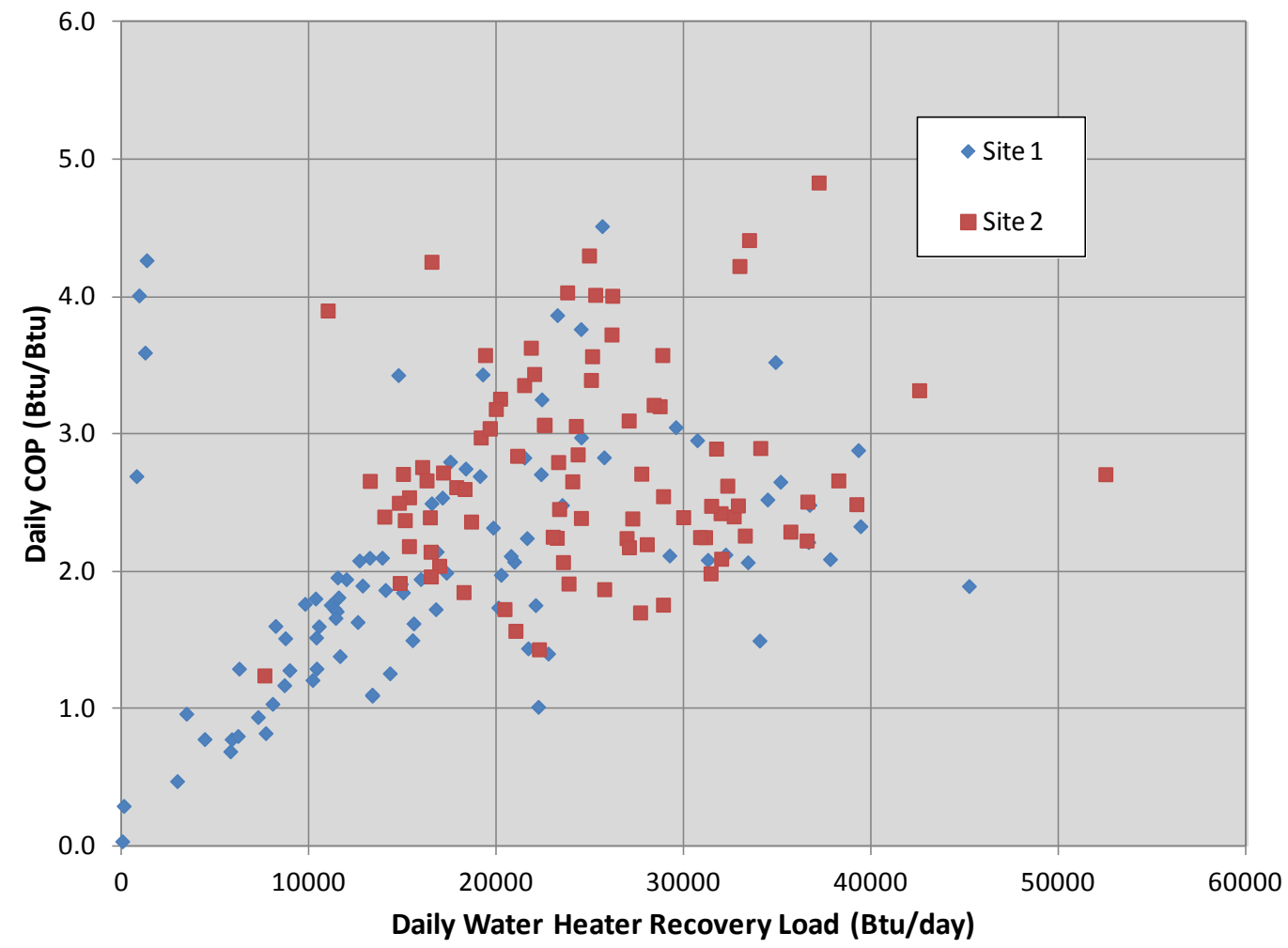

Figure 18. Daily HPWH COP as a function of recovery load 


\subsection{Air Conditioning Impact}

An important goal in this project in addition to documenting HPWH field performance and operating characteristics is to try to quantify the cooling benefit that can be realized in a hot-dry climate. The recent PNNL HPWH report indicated a space-cooling benefit equivalent of approximately $1.5 \mathrm{kWh}$ /day at a hot water usage level of 78.51 gallons per day (Widder et al, 2014). By measuring HPWH inlet and outlet air temperature and RH conditions and airflow rate $^{15}$, one can calculate the sensible and latent cooling delivered by the unit. Figure 19 plots a 36 -hour period at Site 2 with two HPWH cycles, both approximately 2.5 hours long. The lower portion of the graph plots evaporator entering and leaving air conditions during the cycles, and the upper portion of the graph plots the delivered cooling to the indoors. Leaving air temperatures are typically $25-30^{\circ} \mathrm{F}$ cooler than entering air, and leaving $\mathrm{RH}$ is $40-50 \%$ higher than the dry indoor inlet conditions. Given the different hot water loads and operating efficiencies at each site, the full-summer average daily delivered cooling varies from 12,000 $\mathrm{Btu} / \mathrm{hr}$ at Site 1 to $17,000 \mathrm{Btu} / \mathrm{hr}$ at Site 2. Although Site 2 had a higher daily HPWH spacecooling benefit, the duration of the cooling season impacts the length of time the cooling benefit actually offsets space cooling energy use.

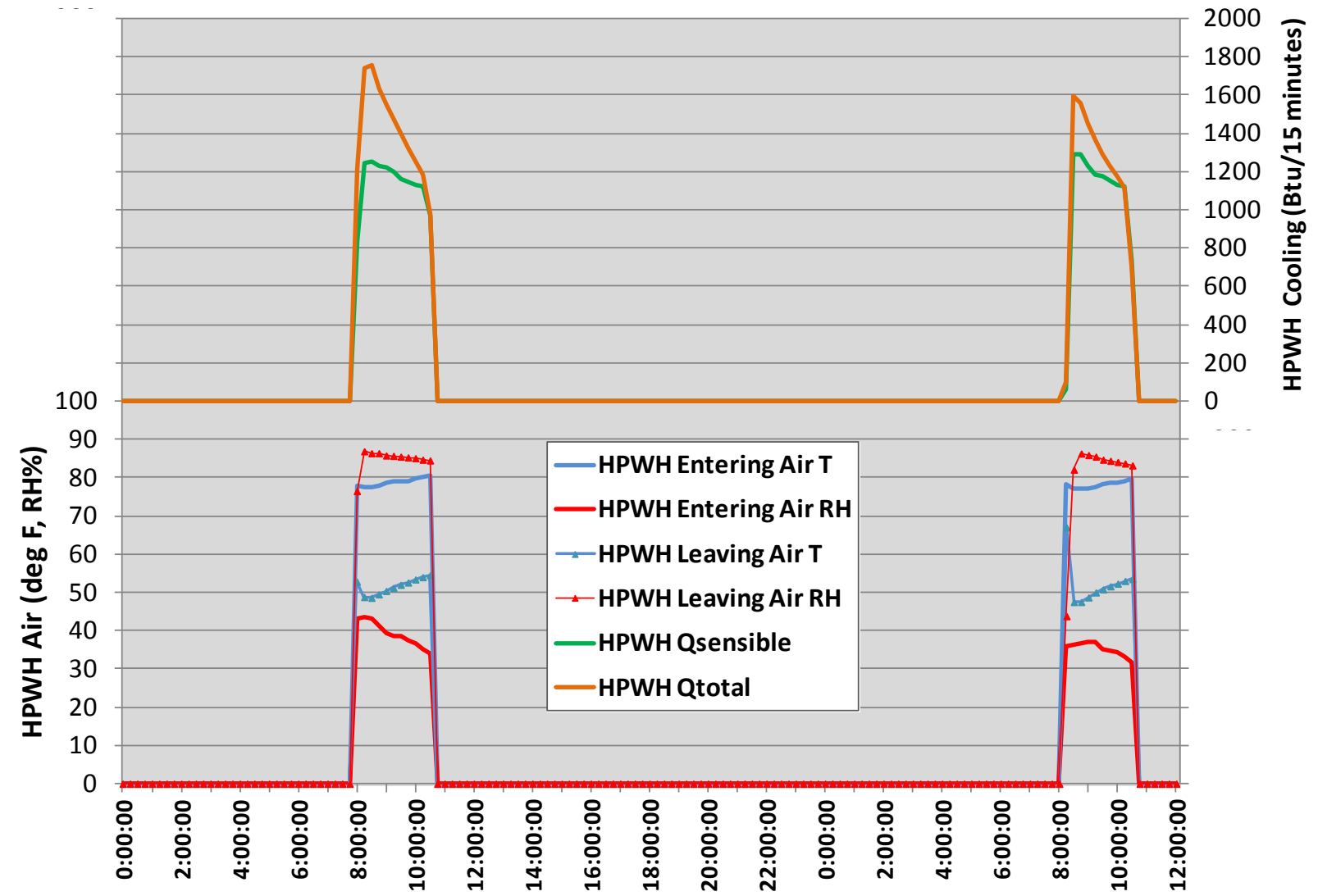

Figure 19. HPWH evaporator air conditions and delivered cooling

\footnotetext{
${ }^{15}$ Using the TEC Flow Blaster device
} 
Monitoring air conditioner energy consumption at each of the two systems installed at both sites allowed characterization of cooling consumption as a function of outdoor temperature. Figure 20 plots total daily space cooling energy use as a function of maximum outdoor temperature. The difference between the two sites is surprisingly significant, as is the lower-than-expected correlation of cooling energy use with outdoor temperature. For the full monitored summer period (May 22 to September 14), Site 1 cooling energy use totaled 7,427 kWh, while Site 2 recorded a much more moderate consumption level of 2,330 kWh. The Site 1 consumption is very high (even by California standards for a very hot climate region) and can likely be attributed to poor equipment efficiencies, high duct losses, and extensive south facing glazing ${ }^{16}$. A significant driver on consumption is thermostat setpoint. Figure 21 plots monitored first-floor indoor temperatures as a proxy for the indoor setpoint. Site 2 occupants tolerate much warmer and more variable indoor temperatures, as well as warmer conditions during the middle of the summer, as evidenced by the shape of second order curve fits to the data.

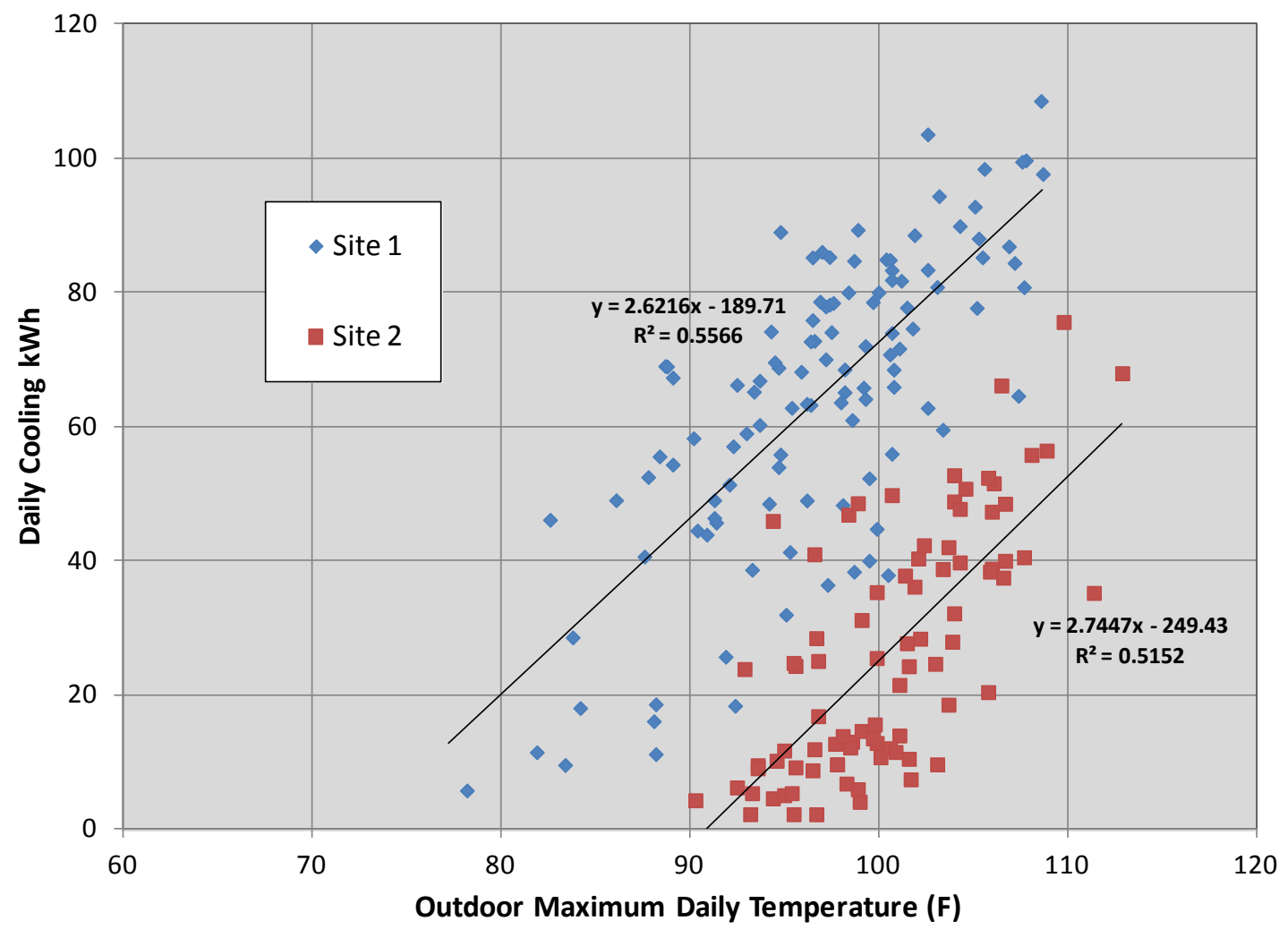

Figure 20. Monitored daily cooling energy use as a function of outdoor maximum temperature

\footnotetext{
${ }^{16}$ This house would make an interesting case study for a deep energy retrofit. This project scope was limited to the HPWH monitoring, otherwise all the identified issues could have been explored in more detail.
} 


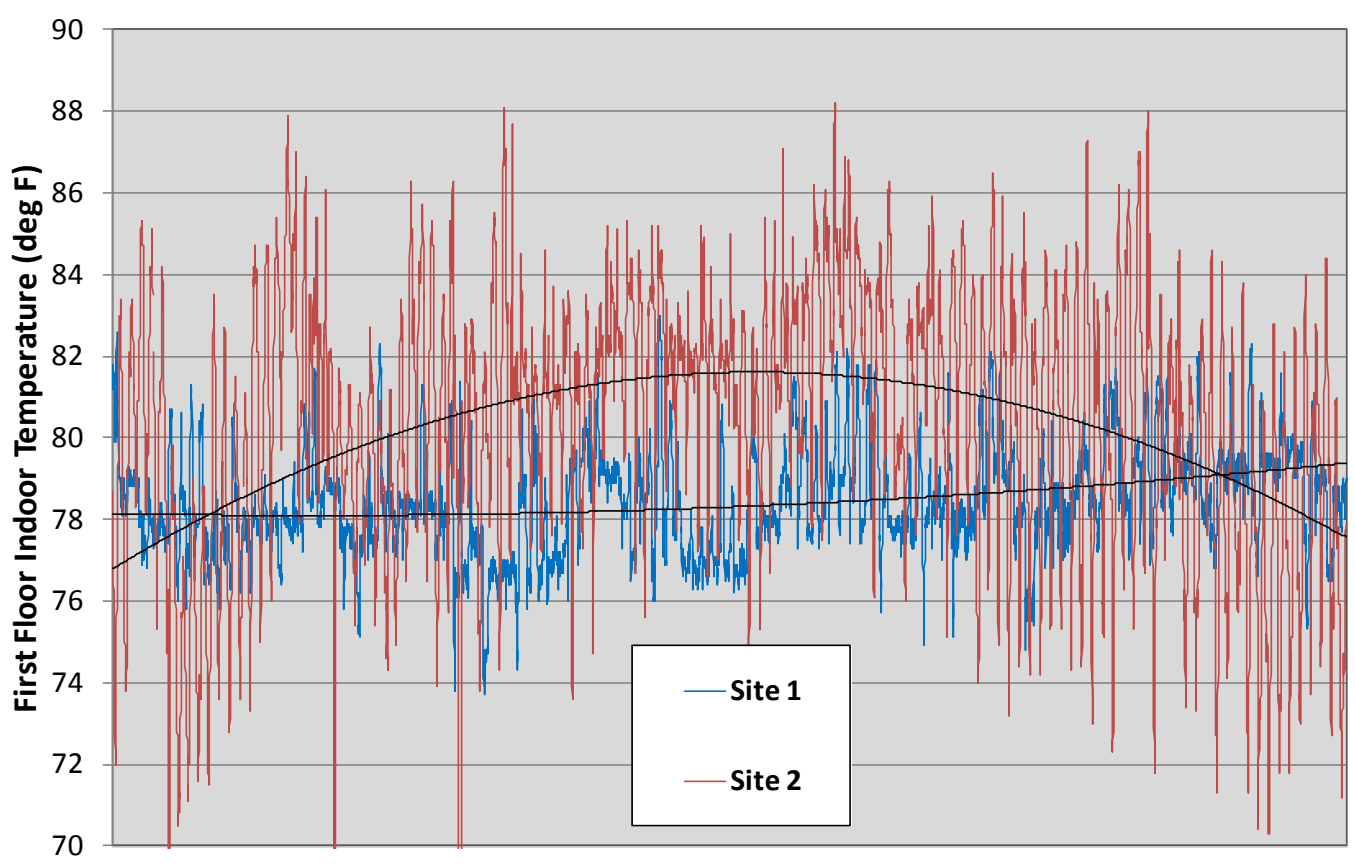

Figure 21. 15 minute interval indoor temperature data (May 22 - September 14, 2014)

\subsection{Ducting Kit Summer Impact}

The HPWH ducting kit provides the ability to optimize system performance seasonally by controlling where evaporator inlet air is coming from (indoors or outdoors) and where the evaporator leaving air is directed (indoors or outdoors). In the heating season, it is preferable to eliminate the HPWH space cooling effect by directing evaporator leaving air outside of the conditioned envelope and using either outdoor or indoor air as the source for evaporator inlet air $^{17}$. In the summer season, the cooling benefit of directing the HPWH leaving air indoors reduces cooling energy use, provided the air conditioner is being operated. Otherwise, the cooling benefit only serves to improve comfort. As shown in Figure 20, where Site 1 initiates cooling at maximum outdoor temperatures $\sim 10^{\circ} \mathrm{F}$ lower than Site 2, variations in house load and comfort expectations have significant impact on the number of days the HPWH provides a space-cooling benefit that offsets a portion of the air conditioning system energy use. Using outdoor air as the evaporator inlet air in a hot climate such as Redding also provides the benefit of reducing the heat pump lift, increasing operating efficiency.

To try to quantify the summer impact of the ducting kit, data were collected from Site 2 in two operating modes: 1) evaporator inlet air from laundry room source (July 1-15), and 2) evaporator inlet air fed by outdoor air duct (August 30-September 14). Table 6 summarizes average outdoor and indoor conditions during that time period, as well as the HPWH evaporator inlet conditions during only the 15-minute logging intervals when the HPWH was operating. The Mode 1 period (using indoor air as the HPWH source) was mid-summer with outdoor temperature averaging

\footnotetext{
${ }^{17}$ If there are indoor combustion appliances or wood burning stoves, depressurizing the house by using indoor air should be discouraged.
} 
$90^{\circ} \mathrm{F}$ and inlet air conditions to the HPWH during operation averaging $83.2^{\circ} \mathrm{F}(\sim 7$ degrees cooler than outdoors) and 32.9\% relative humidity. Later in the summer in Mode 2, average outdoor air conditions were milder $\left(80^{\circ} \mathrm{F}\right)$ and the resulting evaporator inlet air conditions during HPWH operation were slightly warmer $\left(2^{\circ} \mathrm{F}\right.$ warmer than outdoors) and dryer at an average condition of $81.9^{\circ} \mathrm{F}$ and $24.0 \%$.

Ideally, with a vertical thermocouple stalk installed in the storage tank, field data could be used to calculate a 15-minute COP based on the energy added to the tank allowing for direct measurement of the energy input to the storage tank. However, within the scope and practical realities of this field monitoring effort, thermal monitoring was limited to the immersion thermocouple sensors on the water heater inlet and outlet. Performance maps generated during NREL laboratory testing of various HPWHs (Sparn et al, 2014) resulted in a series of plots characterizing HPWH COP variations as a function of evaporator entering air wet-bulb temperature and average tank temperature. These data were reviewed in conjunction with the observed inlet air temperature and $\mathrm{RH}$ data to approximate the magnitude of COP impacts due to varying the source of the inlet air. The NREL performance plots suggest a typical increase in $\mathrm{COP}$ due to $\mathrm{a} 4^{\circ} \mathrm{F}$ increase in wet-bulb temperature was on the order of 0.1 to 0.2 . To get a handle on the expected performance impact of a change in wet-bulb temperature due to the ducting, wet-bulb temperatures were calculated based on a "typical" mid-summer indoor air source condition of $80^{\circ} \mathrm{F}$ and $32.9 \% \mathrm{RH}$, and a corresponding outdoor source air condition of $90^{\circ} \mathrm{F}$ and $24.0 \% \mathrm{RH}$. The resulting calculated $3.5^{\circ} \mathrm{F}$ increase in wet-bulb temperature shown in Figure 22 results in about a 0.1 to 0.2 COP improvement. Based on the conditions observed in this hot-dry climate, the COP impact is fairly small due to the dryer outdoor air partially countering the warmer air temperature; however, in a more humid climate, the benefit may be greater.

Table 6. Impact of Ducting Kit on Summer HPWH Inlet Conditions

\begin{tabular}{|ccccccc|}
\hline & HPWH & \multicolumn{2}{c}{ Outdoor } & \multicolumn{2}{c|}{ Indoor } & \multicolumn{2}{c|}{ HPWH Inlet Air } \\
$\begin{array}{c}\text { Time } \\
\text { Period }\end{array}$ & $\begin{array}{c}\text { Inlet Air } \\
\text { Source }\end{array}$ & $\begin{array}{c}\text { Temperature } \\
\text { (deg F) }\end{array}$ & $\begin{array}{c}\text { RH } \\
\text { (\%) }\end{array}$ & $\begin{array}{c}\text { Temperature } \\
\text { (deg F) }\end{array}$ & $\begin{array}{c}\text { Temperature } \\
\text { (deg F) }\end{array}$ & $\begin{array}{c}\text { RH } \\
\text { (\%) }\end{array}$ \\
\hline $\begin{array}{c}\text { Mode 1: July } \\
\text { 1-15 }\end{array}$ & $\begin{array}{c}\text { Indoors } \\
\text { (Laundry) }\end{array}$ & $89.9^{\circ}$ & $45.9 \%$ & $81.6^{\circ}$ & $83.2^{\circ}$ & $32.9 \%$ \\
\hline $\begin{array}{c}\text { Mode 2: Aug } \\
\text { 30- Sept 14 }\end{array}$ & Outdoors & $80.1^{\circ}$ & $40.6 \%$ & $78.0^{\circ}$ & $81.9^{\circ}$ & $24.0 \%$ \\
\hline
\end{tabular}




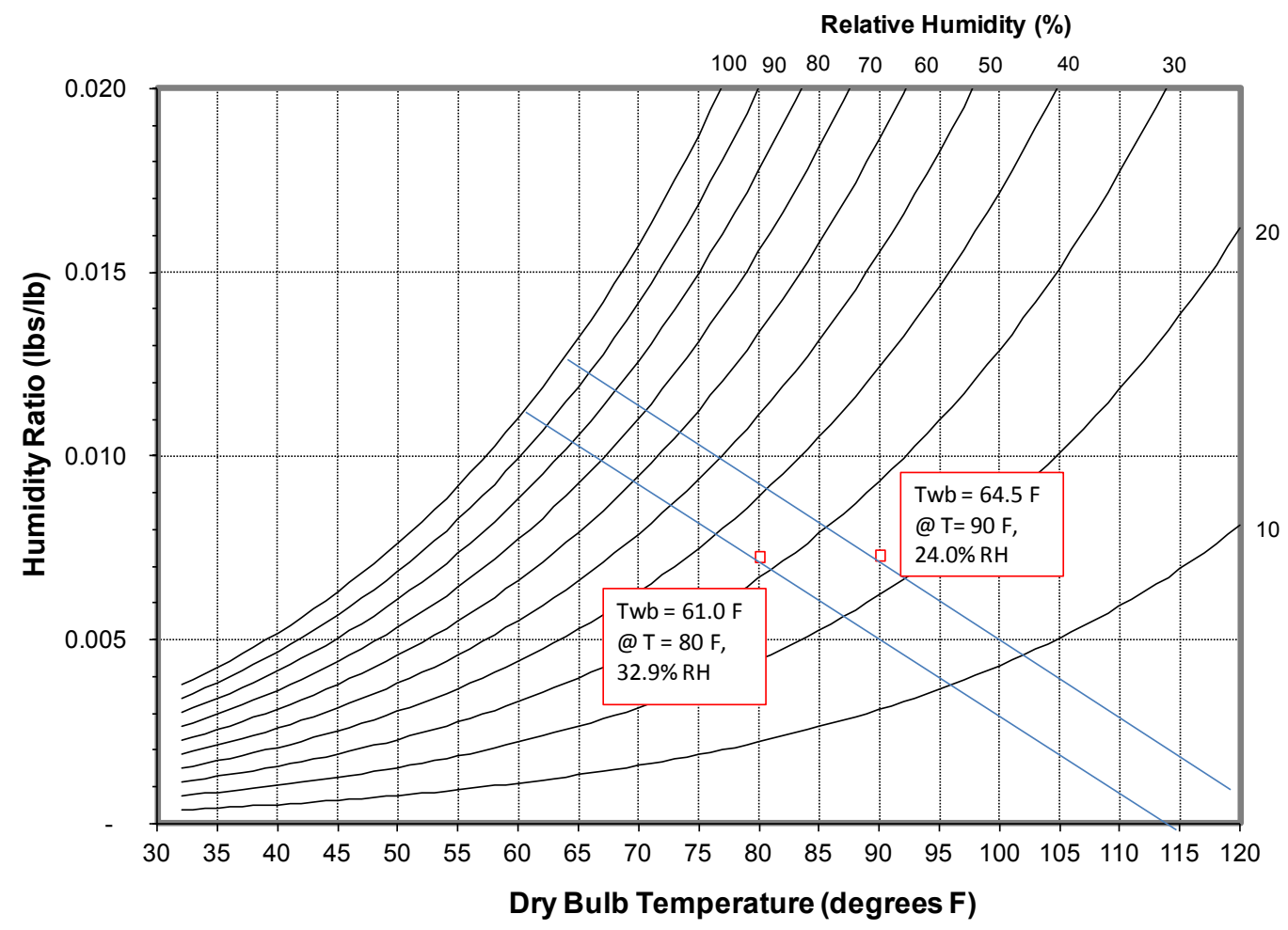

Figure 22. Comparison of average HPWH inlet air conditions on entering wet-bulb temperature

\subsection{Preliminary Annual Savings Projections}

Since heating season monitoring was not feasible within the project completion timeline, only preliminary estimates of annual performance can be developed at this time based on the summer monitoring results and other available data. The field monitoring project continued through the winter with support from utility partners Redding Electric and Pacific Gas and Electric.

The following simplified analysis provides a preliminary indication of full-season impacts in the Redding area. The extrapolations were developed taking into account observed hot water loads and space-cooling benefits, as well as other performance relationships and assumptions that are outlined in full detail in Appendix A. Modeled results presented in NREL's assessment of HPWH performance throughout the United States (Maguire et al, 2013) are relied on heavily in this report as heating season impacts were not monitored. In the NREL study, the impact of an indoor HPWH on an air source heat pump heated home in the hot-dry climate region was estimated at $260 \mathrm{kWh} / \mathrm{year}$.

Table 7 summarizes the key findings from this initial evaluation. Based on the hot water usage estimation from the summer monitoring, base case annual electric storage water heater energy use is determined to be 2,393 kWh for Site 1 and 3,923 kWh for Site 2. Although summer in-situ COPs were higher than the equipment nominal rated energy factor (EFs) since operating conditions were more favorable, an annual operating COP equal to the EF was used as a full-year estimate of annual HPWH performance. HPWH annual water heating savings relative to electricresistance storage water heater are projected to range from 59-61\%. Space-conditioning impacts 
ranged from an increase in energy usage at Site 1 (135 kWh cooling savings offset by added 260 $\mathrm{kWh}$ heating energy use) to a $121 \mathrm{kWh}$ cooling energy savings at Site 2 (with the ducting kit installed). Applying the fixed Redding Electric utility rate of $\$ 0.1528$ per $\mathrm{kWh}$, the annual $\mathrm{kWh}$ cost savings are projected to range from $\$ 205$ to $\$ 370$. A $\$ 1,800$ incremental cost for a HPWH installation over a standard electric water heater replacement was provided by Mike MacFarland of The Energy Docs. An additional \$500 was assumed for installation of the ducting kit and associated duct work, grilles, and required detailing work at Site 2 . The resulting preliminary simple paybacks for the two installations are in the $6.2-8.8$ year range, before any potential incentives are applied ${ }^{18}$.

Table 7. Preliminary Annual Performance Projections

\begin{tabular}{lcc}
\hline \multicolumn{1}{c}{ Parameter } & Site 1 & Site 2 \\
\hline Monitored gallons/day & 44.4 & 66.9 \\
$\begin{array}{l}\text { Estimated Base Electric Storage Water } \\
\text { Heater Electrical Consumption, kWh/year }\end{array}$ & 2,393 & 3,923 \\
& & \\
Estimated Annual HPWH Electrical & 927 & 1,623 \\
Consumption, kWh/year & 1,466 & 2,300 \\
$\begin{array}{l}\text { DHW Savings, kWh/year } \\
\text { Space Conditioning Savings (kWh/year) }\end{array}$ & -125 & 121 \\
\hline Total Savings, kWh/year & 1,341 & 2,421 \\
Annual Savings, \$/year & $\$ 205$ & $\$ 370$ \\
Simple Payback, years & 8.8 & 6.2 \\
\hline
\end{tabular}

\subsection{Initial Homeowner Reactions}

Informal communications with the homeowners at each site provided some feedback on performance and satisfaction issues related to the installation of the HPWHs.

\section{Site 1:}

On a $1-5$ satisfaction level ( 5 being highest), the occupant gave the new unit a 3 . They would have given it a 4, but the control problems (no hot water) when switching to electric-resistanceonly mode was a major discomfort over a two-day period. In terms of what they like best, "...the look and the option of the cold air for cooling the space." The unit "seems to be providing enough hot water" and "the noise levels have not been an issue". The key benefit for the occupant is the cool air the unit provides and the feeling is that the ducting kit is not necessary for the homeowner's application.

\footnotetext{
${ }^{18}$ http://www.dsireusa.org/ provides information for the entire United States on available incentives and rebates.
} 
Site 2:

On the 1-5 satisfaction level, the occupant gave the new unit a 4. "The only reason it's not a 5 is our electric bill has gone up significantly since we have had the HPWH" ${ }^{19}$. In terms of best aspects of the unit, they identified three: "more hot water... Can take two showers at a time.... and, the cold air delivered to the kitchen." What they didn't like pertains to the perceived higher energy bills. The hot water delivery performance is "way better," they have yet to run out of hot water with the new unit, and they have no concerns with noise with the laundry room location.

${ }^{19}$ This comment was of particular interest as the monitoring data characterizing daily water heating electrical use before and after the HPWH retrofit clearly suggests the opposite effect. Higher 2014 utility bills may well be due to higher cooling energy consumption versus 2013. Homeowner perceptions, whether right or wrong, are important. 


\section{Conclusions}

This project was valuable in extending indoor HPWH field data monitoring and evaluation efforts into hot-dry climate regions, complementing research that has been completed or is underway in other parts of the United States and Canada. The hot-dry region, with its long and hot summers, offers an ideal opportunity for delivering enhanced energy savings and improved comfort to many U.S. households. Although Redding is a hot climate with many days exceeding $100^{\circ} \mathrm{F}$ each year, other parts of the desert Southwest have longer and hotter summers where space-cooling benefits will be greater.

Monitored performance during the late-May to mid-September monitoring period suggested good HPWH performance with in-situ COPs ranging from 2.60 to 2.85. Other than a period of short experimentation with electric-resistance water heating at one site, monitored backup electric element operation contributed only 4-7\% of the total monitored HPWH energy use. As the weather turns to fall and winter, and cold water inlet temperatures and HPWH entering air temperatures fall, the expectation is that backup electrical usage will increase.

The three primary research questions addressed include:

1. What level of cooling energy savings can be achieved by a ducted HPWH in a hot-dry climate with more than 1,900 cooling degree days?

2. What is the general level of homeowner satisfaction with the indoor HPWH in terms of perceived energy savings, hot water delivery characteristics, noise, and thermal comfort impacts?

3. Based on the field testing results, what recommendations can be made to improve the ducted HPWH installability, operation, and performance?

\subsection{Level of Cooling Energy Savings that can be Achieved}

The expectation entering the project was that a consistently hot climate might provide a stable testing environment to facilitate statistically determining the benefit of HPWH space-cooling benefit relative to the whole-house cooling energy requirements. This was not proven out in this testing as the daily cooling energy usage was much more variable between comparable days than anticipated. In addition, the cooling loads at the two houses (Site 1 in particular) dwarfed any contribution from the HPWH. The monitoring approach for this study allowed for calculating the Btus of cooling energy the unit delivered to the indoor space. Extrapolating these data at each site over a full cooling period indicated projected space cooling reductions of $121-135 \mathrm{kwh} /$ year. These results were generated in older homes with less efficient envelopes and dated HVAC systems. Whereas these results may be representative of a Redding retrofit application, impacts in a thermally improved new construction house in this climate will likely be lower due to a shorter cooling season.

\subsection{General Level of Homeowner Satisfaction}

The two households were generally pleased with the installed HPWH. Key benefits identified were improved hot water delivery and system heating capacity, beneficial space cooling, and low noise. Site 2 with the six-person household noted immediate and significant improvement in the 
unit's ability to provide hot water compared to their prior electric storage water heater. Ongoing monitoring through the winter will be valuable in terms of assessing winter impacts on energy savings, hot water delivery, and thermal comfort. Site 1 experienced some dissatisfaction when testing in electric-resistance mode as the unit stopped operating, leading to two days without hot water.

\subsection{Recommendations to Improve the Ducted HPWH Installability, Operation, and Performance}

The installer indicated no significant issues with installing the unit at either site. The 80-gallon unit may provide some challenges in some applications due to its larger size. Installation of the ducting is a site-dependent issue and there may be situations where the 25-foot length limit may make installations challenging.

With the exception of the control board problem at Site 1, the installed units operated reliably and efficiently. The appearance and control panel of the unit provide for a quality customer aesthetic. The control board issue at Site 1, as well as the associated delay in procuring a new board, were the only negative experiences encountered to date.

As with all HPWHs, the control sequence as it relates to resistance heat operation plays a significant role in determining system efficiency. During the summer months, resistance heating represented $4-7 \%$ of total unit consumption. Although relatively small, the impact will grow as the inlet water gets colder and hot water consumption increases in winter. Optimizing the control sequence for HPWHs represents an ongoing effort for the industry. 


\section{References}

Department of Energy. 2010. EnergyStar ${ }^{\mathrm{TM}}$ Water Heater Market Profile. Prepared for Oak Ridge National Laboratory under contract BOA\#4200000327.

Fluid Market Strategies. 2013. NEEA Heat Pump Water Heater Field Study Report. NEEA Report \#E13-266, Northwest Energy Efficiency Alliance, Portland, OR. Available at: http://neea.org/docs/default-source/reports/heat-pump-water-heater-field-studyreport.pdf?sfvrsn $=5$

Hoeschele, M.; Weitzel, E. 2013. "Monitored Performance of Advanced Gas Water Heaters in California Homes”, ASHRAE Transactions, Vol. 119, Part 1, p 214-225.

Maguire, J.; Burch, J.; Merrigan, T.; Ong, S. 2013. Energy Savings and Breakeven Cost for Residential Heat Pump Water Heaters in the United States. NREL/TP-5500-58594, National Renewable Energy Laboratory, Golden, CO. Available at: http://techportal.eere.energy.gov/techpdfs/HPWH_mapping.pdf

Shapiro, C.; Puttagunta, S.; Owens, D. 2012. Measure Guideline: Heat Pump Water Heaters in New and Existing Homes. DOE/GO- 102012-3456. Available at: http://www.nrel.gov/docs/fy12osti/53184.pdf

Sparn, B.; Hudon, K.; Christensen, D. 2014. Laboratory Performance Evaluation of Residential Integrated Heat Pump Water Heaters. NREL/TP-5500-52635, National Renewable Energy Laboratory, Golden, CO. Available at: http://www.nrel.gov/docs/fy14osti/52635.pdf

Widder, S.; Peterson, J.; Parker, G.; Baechler, M. 2014. Impact of Ducting on Heat Pump Water Heater Space Conditioning Energy Use and Comfort. PNNL-23526. Pacific Northwest National Laboratory, Richland, WA. Available at:

http://www.pnnl.gov/main/publications/external/technical_reports/PNNL-23526.pdf

Williamson, J.; Puttagunta, S. 2013. "Systems Evaluation at the Cool Energy House." Golden, CO: National Renewable Energy Laboratory. DOE/GO -102013-3942. Available at: http://apps1.eere.energy.gov/buildings/publications/pdfs/building america/systems eval cool e nergy house.pdf. 


\section{Appendix A: Determination of Preliminary Annual Performance Impacts}

It was necessary to extrapolate from the available summer-only field data available to develop an initial performance projection for the installed HPWHs. The methodology used to arrive at an annual electric and cost savings is documented here and will be refined when full-season field performance is available. The applied method is simplified, but provides for a first-cut performance estimation.

\section{Step 1: Develop annual hot water load estimate}

Based on field monitoring data, hot water loads for Site 1 equaled $44.4 \mathrm{gpd}$ and $66.9 \mathrm{gpd}$ for Site 2. This was used to represent annual hot water usage, although one would expect usage to increase during the winter months.

\section{Step 2: Estimate base case electric storage water heater energy use}

Figure 17 provides linear curve fits for electric storage water heater daily energy use as a function of load. Three seasons were identified to reflect varying hot water usage to inlet water temperature effects, and to lesser extent changing storage losses. Winter was expected to encompass four months (December - March), spring/fall two months (April, November), and summer the remaining six months. Daily energy use for the loads identified in Step 1 was calculated according to the following equation:

Daily electric storage $\mathrm{kWh}=0.75+\operatorname{gpd} \times \mathrm{A}$

(where $\mathrm{A}=.117$ for summer, .137 for spring/fall, and .157 for winter)

Determine seasonal energy use by summing number of days in each season; sum for annual

\section{Step 3: Estimate HPWH energy use}

HPWH annual energy use = electric storage annual $\mathrm{kWh} * 0.91 / \mathrm{HPWH}$ EF

0.91 is applied as a representative electric water heater annual performance value

\section{Step 4: Determine space-cooling benefits}

Annual space cooling impacts were estimated based on the 1.0- and 1.4-ton-hour/day benefits monitored for Sites 1 and 2, respectively. To translate this to annual impacts, one needs to a reasonable cooling system efficiency, as well as an estimate of the number of days that the space-cooling benefit is directly contributing to a reduction in cooling energy. To get a conservative estimate of energy savings, the applied efficiency (i.e., full-season energy efficiency rating) of 12.0 was assumed, resulting in $1 \mathrm{kWh} /$ ton-hour delivered. This results in daily savings of 1.0 and $1.4 \mathrm{kWh} /$ day (Sites 1 and 2, respectively). Based on the space cooling day as a function of outdoor maximum temperature (Figure 20) and the 2014 Redding summer weather, a total of 135 days of cooling reduction benefit was estimated for Site 1 and 86 days for Site 2. Multiplying the daily benefit by the number of days generates the 121 to $135 \mathrm{kWh}$ annual space-cooling benefit, equal to $2-5 \%$ of the monitored space cooling usage. 


\section{Step 5: Estimate space-heating impacts}

Site 1 has an indoor HPWH without ducting kit, while Site 2 has a ducting kit and is therefore presumed to be operated with the manual dampers positioned to obtain the full summer benefit and avoid any heating season penalty. Without any monitored based for heating season impacts for Site 1, projections were used from an NREL modeling study entitled "Energy Savings and Breakeven Cost for Residential Heat Pump Water Heaters in the United States" (Maguire et al, 2013). In Table 2 of Appendix $C$ from that study, the source energy impact of an indoor HPWH operating in a hot-dry climate with an air source heat pump was projected to be an increase in heating energy use of $2.79 \mathrm{MMBtu} / \mathrm{year}$. Converting source energy to $\mathrm{kWh}$ using the NREL source energy multiplier of 3.15 results in an added $260 \mathrm{kWh}$ of space heating usage.

\section{Step 6: Calculate total energy savings}

HPWH water heating and space heating and cooling impacts are summed.

\section{Step 7: Calculate total operating cost savings}

Electrical savings are converted to dollars at the fixed electric rate of $\$ .1528 / \mathrm{kWh}$.

\section{Step 8: Calculate simple payback}

Mike MacFarland of The Energy Docs estimated a typical HPWH replacement of an existing electric storage water heater costs $\sim \$ 3,000$ vs. $\$ 1,200$ for a direct electric storage replacement. The $\$ 1,800$ incremental cost for the HPWH installation increases to approximately $\$ 2,300$ at Site 2 for adding the ducting kit, added duct work, and other installation detailing. Resulting simple paybacks for the two installations are in the 6.2- to 8.8-year range, before any potential incentives are applied.

Preliminary economic evaluation of the ducting kit suggests an annual energy savings of 381 $\mathrm{kWh}(260 \mathrm{kWh}$ heating plus $121 \mathrm{kWh}$ cooling). Under the Redding Electric utility rates and a cost of $\$ 500$, the simple payback is a projected at 8.6 years. 
Table A1. Performance Projections for Installed HPWHs

\begin{tabular}{lcc}
\hline \multicolumn{1}{c}{ Parameter } & Site 1 & Site 2 \\
\hline Monitored gallons/day & 44.4 & 66.9 \\
\hline $\begin{array}{l}\text { Estimated Base Electric } \\
\text { Storage WH kWh/year }\end{array}$ & 2,393 & 3,923 \\
\hline Assumed Annual COP & 2.35 & 2.20 \\
\hline $\begin{array}{l}\text { Estimated Annual HPWH } \\
\text { kWh/year }\end{array}$ & 927 & 1,623 \\
\hline DHW Savings, kWh/year & 1,466 & 2,300 \\
\hline Cooling Savings, kWh/year & 135 & 121 \\
\hline $\begin{array}{l}\text { Cooling Savings as a \% of } \\
\text { Annual Space Cooling kWh }\end{array}$ & $2 \%$ & $5 \%$ \\
\hline $\begin{array}{l}\text { Heating Savings, kWh/year } \\
\text { Total Savings, kWh/year }\end{array}$ & -260 & 0 \\
\hline Installed Incremental Cost & $\$ 1,341$ & 2,421 \\
\hline Annual Savings, \$/year & $\$ 205$ & $\$ 2,300$ \\
\hline \begin{tabular}{l} 
Simple Payback, years \\
\hline
\end{tabular} & 8.8 & $\$ 370$ \\
\hline
\end{tabular}


